\title{
Čínský zachránce? Narativní obrazy zahraničí ve vybraných projevech českých politiků v období první vlny coronavirové krize
}

\author{
Chinese saviour? Narrative images of foreign countries in selected speeches \\ of Czech politicians during the first wave of the coronavirus crisis
}

\section{JAKUB PALEČEK*1}

${ }^{*}$ Department of Politics and International Relations, Faculty of Arts, University of West Bohemia, Czech Republic

\begin{abstract}
This paper deals with the foreign policy narratives of selected actors of Czech foreign policy. It focuses on narratives about all foreign countries mentioned by the examined actors during the initial phase of the problems related to COVID-19 in the Czech Republic (March 2020). The politicians (members of the government and the President) indicated their foreign policy ideas in specific narratives. The aim of the paper is to corroborate the thesis that in a crisis situation caused by the COVID-19 pandemic, selected politicians used foreign policy narratives to communicate their foreign policy ideas. It seeks to contribute to the understanding of the role played by narratives in the formation of foreign policy ties, of the actual content of those narratives, and of the ways their meaning is constructed. Narrative analysis of metaphors is the paper's research method. The paper finds that the politicians' narratives focused on the People's Republic of China in particular. Using a narrative set in the "backdrop" of a global pandemic, they highlighted positive metaphors about China's role and character while setting back any criticism. Other countries of the world were not in the narrative focus, they were only metaphorically framed to a lesser extent and in various meanings. The politicians, therefore, used the crisis to articulate a foreign policy leaning towards China. The given narrative was, in a sense, a part of the foreign policy of the Czech Republic because it contributed to its discursive dimension.
\end{abstract}

\section{Keywords}

Czech politics, narrative, foreign policy, metaphor, China, coronavirus

DOI: https://doi.org/10.24132/cejop_2020_3

How to cite: Paleček, J. 2020. “Čínský zachránce? Narativní obrazy zahraničí ve vybraných projevech českých politiků v období první vlny coronavirové krize." Central European Journal of Politics 6 (2): 44-72. DOI: 10.24132 /cejop_2020_3

\footnotetext{
${ }^{1}$ Address: Mgr. Jakub Paleček, PhD candidate, Department of Politics and International Relations, Faculty of Arts, University of West Bohemia, Jungmanova 1, 30100 Pilsen, Czech Republic. E-mail: jpalecek@kap.zcu.cz
} 


\section{1. Úvod}

První měsíce roku 2020 byly celosvětově poznamenány společenskou krizí způsobenou pandemií nemoci COVID-19. Vypukla v Číně jako lokální epidemie, rychle se šírila do celého regionu Jihovýchodní Asie a zanedlouho díky globálnímu propojení postihla téměř celý svět. Česká republika byla zasažena v březnu. K akutnímu zdravotnímu ohrožení se brzy přidalo vědomí nastávající ekonomické recese v důsledku přijatých politických opatření, která měla za cíl redukovat šíření viru SARS-Cov-2. Politici na tiskových konferencích a téměř všechna média v zemi přestala referovat o jiných událostech a všechna pozornost se upřela na situaci kolem nového coronaviru. Jako nejpalčivější problém se brzy ukázal zásadní nedostatek zdravotnického materiálu a Vláda ČR se dostala pod silný tlak kritiky z mnoha stran. Reagovala na něj zvýšenou kadencí politických prohlášení skrze různé komunikační kanály (zejm. denní tiskové konference, sociální sítě a rozhovory v médiích). Tato prohlášení měla jeden výrazný rys, který zavdal příčinu k sepsání této studie: akcentování role Čínské lidové republiky (dále jen Číny). ${ }^{2}$

Např. prezident Zeman se vyjádřil následovně: „[...] problémem je výrazný nedostatek zdravotnických prostředků. Chtěl bych proto poděkovat Čínské lidové republice, která nám jako jediná země pomohla v dodávce těchto prostředkư" (Zeman 2020b). Podobných výroků o roli Číny v celé krizi bylo více. Otázky vzbudila například tisková konference př́mo na letišti po př́letu letadla se zdravotnickými pomůckami právě z Číny. Pro kontext lze doplnit, že toto se odehrávalo v situaci dlouhodobého štěpení politické reprezentace ČR ve vztahu k Číně. Civilní kontrarozvědka ČR dlouhodobě upozorňuje na rostoucí nepřátelské aktivity čínských zpravodajských služeb a vlivových sítí (BIS 2019). V posledních letech jsme mohli zaznamenat řadu kontroverzních událostí ukazujících na tento jev (např. násilné potyčky s pro-čínskými aktivisty při návštěvě prezidenta Si Ťinpchinga v Praze v roce 2016). Situace se pak značně vygradovala sporem o diplomatickou návštěvu Tchaj-wanu, kterou chtěl realizovat předseda senátu Kubera, ale ostře proti ní se postavil prezident Zeman i premiér Babiš. Kubera od čínského velvyslance obdržel vysoce kontroverzní dopis oznamující sankce za návštěvu Tchaj-wanu a několik dní nato zemřel na infarkt. Dodnes pokračuje tenze mezi Zemanem a novým předsedou Senátu Vystrčilem, jak o okolnostech politického tlaku Číny skrze tzv. „čínský dopis“, tak o cestě na Tchaj-wan.

Na druhou stranu je logické, že politici ve své rétorice nehovoří pouze o Číně. Ve svých krizových projevech tematizují i další země světa. Výzkum promluv o Číně byl na jednu stranu motivem pro výzkum, na druhou stranu je však potřeba se zabývat i promluvami o jiných státech světa. Výzkum narativů pouze o Číně by byl deskriptivní a jeho výzkumná otázka by byla banální. Chyběl by v něm kontext diskurzivního vztahu

\footnotetext{
${ }^{2}$ Jako autor studie vycházím z normativního postoje, který je vůči tomuto př́stupu kritický. Tento postoj ovlivnil výběr tématu.
} 
k dalším zemím. Proto kvůli logické i metodologické koherenci studie není vhodné vyloučit výzkum narativů o dalších státech. Je totiž možné, že afilace k Číně jde ruku v ruce s distancováním se od jiných aktérů (typicky EU). Právě toto je moment, který činí výzkumné otázky tohoto textu nebanálními, protože byt’ se mohou projevy o Číně zdát lehce dekódovatelné, s celosvětovým kontextem už to tak snadné není. Na níže položené otázky zkrátka neexistuje jednoznačná odpověd', kterou by bylo lze pronést bez výzkumu.

Všechny zmíněné okolnosti vyvolávají řadu otázek spojených sideovým zahraničněpolitickým př́klonem aktérů zahraniční politiky (k tématu viz Fürst a Pleschová 2010; Kratochvíl 2015; Bartovič 2016; obecně viz Weis a Řiháčková 2010). Krize spojená s COVID-19 poskytla jedinečnou př́ležitost k pozorování tohoto fenoménu. Máme $\mathrm{k}$ dispozici velké množství výroků zaznamenaných $\mathrm{v}$ krátkém krizovém okamžiku. Máme tedy výbornou možnost zachytit surový politický diskurz a způsob jeho (re)produkce. Tento nový úhel pohledu pomůže objasnit, co bylo významovým obsahem zahraničněpolitických promluv a jaká byla jejich funkce. ${ }^{3}$ Právě o to se bude snažit tato studie, která se zabývá narativy v diskurzivní dimenzi zahraniční politiky vybraných aktérů. Konkrétně se zaměřuje na narativy o zahraničí, tj. o všech vnějších entitách (státech), o kterých zkoumaní aktéři hovořili během úvodní fáze problémů spojených $\mathrm{s}$ COVID-19 v České republice (březen 2020). Jednalo se o tzv. první vlnu nemoci a souvisejících vládních opatřeních. Následovalo letní uvolnění podmínek a menší kadence vládní rétoriky. Druhá vlna přišla zhruba v září téhož roku a v době psaní tohoto textu stále trvá.

Tato studie vychází z předpokladu, že aktéři zahraniční politiky konstruují, reprodukují a využívají vyprávění o jiných státech (viz níže). V tomto vyprávění (narativu) je př́tomno předporozumění světu ze strany vypravěče, určitá př́iběhová zápletka, ve které je jednotlivým událostem, postavám př́iběhu a jejich rolím přiřazován smysl, a konečně také porozumění toho, kdo příběh reinterpretuje. Aktéři v konkrétním vyprávění naznačují svůj ideový př́íklon k určitým zahraničním entitám (státům) a právě v tomto smyslu jsou tato vyprávění součástí jejich zahraniční politiky. Proto budou zkoumány přímé promluvy aktérů, kteří měli ve sledovaném období klíčový vliv na zahraniční politiku ČR. Jedná se o členy Vlády ČR a prezidenta ČR. Naopak záměrně opomenuti jsou další aktéŕi, kteří mají v nekrizových situacích a vdlouhém období možnost projektovat svůj vliv na zahraniční politiku (např. poslanecké výbory, opozice, velvyslanci, státní agentury či nestátní organizace). Ti všichni neovlivňovali ve zkoumaném období zahraniční politiku přímo ani razantně, at’ už kvůli krizovým opatřením nebo prozaicky kvůli př́liš krátké době na ovlivnění čehokoliv a jejich role byla

\footnotetext{
${ }^{3}$ Další otázkou zcela mimo rámec tohoto textu je, jak byla rámována krize samotná. Logicky se nabízejí velice časté válečné metafory. Hovořilo se o leteckém mostu (viz níže), o první linii, o válce s virem apod. Zajímavé je také podobenství o potápějící se lodi: „když teče do lodi voda, musí všichni k pumpám“ (Zeman 2020a).
} 
výrazně upozaděna. ${ }^{4}$ Zkoumané období je březen 2020. Jedná se o poměrně striktní zúžení výzkumného pole. To je provedeno záměrně s cílem zachytit rétoriku rané fáze krize. Výzkumné otázky (viz níže) jsou této redukci přizpůsobeny. ${ }^{5}$

Cílem práce je hlubší porozumění toho, zda a jak zkoumaní klíčový aktéři české zahraniční politiky (Vláda ČR a prezident ČR) využili krizi spojenou s pandemií COVID-19 $\mathrm{k}$ artikulaci ideové afilace (či naopak hostility) vůči zahraničí. Tento cíl bude dosažen zodpovězením následujících výzkumných otázek: (1) Jaké státy zkoumaní aktéři „narativizovali“ a jakým způsobem a v jaké míře tak činili? (2) Využívali zkoumaní aktéři krizi způsobenou pandemií COVID-19 k artikulaci narativu, který v diskurzivní rovině značí ideovou afilaci ke konkrétní zahraniční entitě (státu)? Pokud ano, k jaké?

Smyslem práce je přispět k porozumění tomu, jakou roli ve vytváření zahraničněpolitických diskurzů hrají vyprávěné narativy, co je vlastně jejich obsahem a jak je jejich význam konstruován. Analýza tohoto jevu umožní lépe chápat zahraničněpolitické směřování vybraných současných lídrů české politiky a pomůže jako vodítko vtom, na které její aspekty je dobré nezapomínat, pokud se pokoušíme jí porozumět. ${ }^{6}$

Text se zabývá zahraniční politikou a jeho disciplinárním zázemím jsou mezinárodní vztahy, na jejichž poli implicitně pracuje s konstruktivistickými (např. Wendt 1999) a poststrukturalistickými (např. Campbell 1999) teoretickými pozicemi. Zároveň se však pohybuje voblasti, která je danými teoriemi stále nedostatečně probádána, a proto sahá mimo vlastní obor pro oporu na úrovni meta-teorie. Ontologická a epistemologická východiska textu jsou v hermeneutice a experiencialismu, konkrétní metodologický postup se inspiruje v kognitivní lingvistice a naratologii (viz níže kapitola 2).

\footnotetext{
${ }^{4}$ Např. Zahraniční výbor se sešel 4. března a následně až 30. dubna.

${ }^{5}$ Otázkou hodnou pozornosti je, zda se zkoumaný narativ nezměnil v následujících měsících. Nepovažuji to za relevantní proto, že je záměrně zkoumáno krizové období, ve kterém byly výroky velmi hustě koncentrované. Mimo to i v dalších měsících lze zatím najít hlavně podporu převažujícího narativu (viz např. Petř́íck 2020b).

${ }^{6}$ Proč se výzkum zabývá narativem a nikoliv ideologií nebo mýtem? Tyto tři pojmy jsou v jistém smyslu komplementární a mohou existovat pospolu a působit synergicky. Vypráví-li politik narativ o Číně, konstruuje vlastně mýtus a využívá $\mathrm{k}$ tomu ideologii. Rozdíl spatřuji v primárnosti různých aspektů. Výzkum ideologie zkoumá na prvním místě ideje, hodnoty, koncepty a jejich vzájemnou interakci (viz např. Freeden 1996). Mýtus (mythos) sice znamená vyprávění, ale odkazuje spíše ke konečnosti vyprávěného, k finálnímu obrazu toho, co má být zobrazeno (srov. Eriksen 2008: 161, 328). Bude-li však v následujícím textu řeč o narativu, je upřednostňováno hledisko temporalizace zkoumaného jevu. Narativ může obsahovat splet' ideologických linek nebo vyplynout $\mathrm{v}$ mýtus, ale vždy přitom rozvrhuje čas. Jinak řečeno Konstruuje čas narativní (srov. Ricoeur 2000: 88). Nelze jej detemporalizovat, fenomenologickou redukcí (epoché) jej uzávorkovat na předmět v jakési zkumavce bezčasí (srov. Blecha 2007: 205-215). Pakliže tedy výzkum pátrá, jak a proč je konstruován př́iběh, nemůže se omezovat na detemporalizované jevy.
} 
Výzkumu narativů v zahraniční politice se věnovala již řada odborných studií. Mezi nejvýznamnější patří samozřejmě Campbellovo Writing Security - United States Foreign Policy and the Politics of Identity, ale v nedávné době vyšlo mnoho dalších studií na toto téma (např. Browning 2008; Krebs 2015; Subotić 2016; Tsvetov 2016; Lewis 2009; Oppermann a Spencer 2016; Teitler 2017). Metaforám vzahraniční politice se v nedávném výzkumu věnovala další řada badatelů (např. Marder 2018; Garcia 2017; Drulák 2009). Oproti těmto pracím je předkládaný text inovativní v několika bodech. Za prvé, kombinuje narativní analýzu s analýzou metafor v provázaném metodologickém postupu a tím pádem zahrnuje všechny klíčové dimenze zkoumání nezjevného v diskurzu - prostředek, způsob i význam konstrukce. Za druhé, díky využití Ricoeurova integrativního modelu narativu, který ve výzkumu mezinárodních vztahů dosud není uplatňován, je výzkum schopen koherentně pojmout všechny bytnosti narativu (kdo, proč a jak jej vypráví a jak je možné jej interpretovat) a tím o něm pojednat v celé jeho komplexnosti. Za třetí, výzkum pojednává o tématu současné mezinárodní politiky, které je dosud poměrně málo odborně zpracované.

Tento text je rozdělen do několika částí. Nejprve budou uvedeny filosofická báze a teoretická východiska narativu (kapitola 2). Dvěma klíčovými pojmy studie jsou „metafora“ a "narativ" a bude třeba předložit jejich teoretické zázemí. Kapitola 3 koncepty zasadí do disciplíny mezinárodních vztahů a vyústí voperacionalizaci pojmu zahraničněpolitický narativ. Následující kapitola bude věnována metodologii výzkumu a představí inovaci v použití daných metod. Pátá kapitola bude věnována samotné narativní analýze metafor v projevech zkoumaných aktérů. $\mathrm{V}$ závěru budou výstupy analýzy interpretovány vůči zvolené teorii a dojde k zodpovězení výzkumných otázek a tím i k naplnění cíle a zhodnocení jejího smyslu.

\section{Pravda, metafora a narativ}

Tato stat' se zabývá něčím, co je jen velmi těžko exaktně uchopitelné, natož měřitelné. Zabývá se něčím, co je nezjevné, skryté. Avšak tato skrytost je na druhou stranu přesně tím důvodem, proč je třeba fenomén zkoumat ( $\mathrm{v}$ konečném důsledku je potřeba porozumět směřování české zahraniční politiky). Práce přitom vychází z předpokladu, že nezjevné zkoumat lze, jen je $\mathrm{k}$ tomu třeba vhodně zvolit metodu bádání vycházející z ověřené vědecké tradice. Proto tato práce vychází z hermeneutiky. Ta odmítá možnost objektivistického uchopení sociální reality, protože objektivita je „konstruována $z$ prostředků a podmínek pozorování" (Blecha 2004: 144). Tzv. fakta, která nepochybně existují, významně souvisejí s celou paletou okolností, včetně niterních procesů subjektu, který fakta nějakým způsobem vnímá. Tato studie tedy předmět svého bádání chápe jako intersubjektivní sociální jev, který neexistuje sám o sobě (pro sebe), není všem, kteří jej 
nazírají, samo-zřejmý a proto je třeba jej uchopit jako fenomén ${ }^{7}$ a následně jej interpretovat. Pravda vyjádřená v určitém narativu „[...] je vždy relativní vůči porozumění, jež je založeno na neuniverzálním pojmovém systému“ (Lakoff a Johnson 2002: 245). Je úzce navázána na kategorizaci daného fenoménu, tedy na výběr určitých jeho prvků, které jsou zvýrazněny, za současného potlačení ostatních aspektů, a tím vloženy do určité kategorie.

Výše nastíněnému fenoménu modelově odpovídá i zahraničněpolitický narativ. Ten může např. podle korespondenční teorie obsahovat stoprocentně pravdivé výroky, ${ }^{8}$ protože může např. pouze konstatovat fakta ve smyslu „kdy a co se stalo“. Nicméně význam těchto faktů je významem vždy pro někoho a jakoukoliv interpretaci nelze oprostit od určitého úhlu pohledu a určitého kontextu. Součástí takto pojatého fenoménu je tedy i to, v jaké podobě a jakým zpơsobem je artikulován. Obě tyto dimenze se podle hermeneutické teorie prolínají ve dvou hlavních prvcích řeči, kterými je metafora a narativ. Význam narativu totiž není odvoditelný z univerzálního překladu jednotlivých slov, gramatických souvztažností a esenciálních bází přítomných pojmů (pozitivistický pohled). Jeho význam spíše plyne z interakce přítomných metaforických pojmů (pohled hermeneutický).

Metafora není pouze umělecká hra slov. Je jedním ze základních prvků lidské řeči a je tudíž podstatnou diskurzivní strukturou (Drulák 2009: 60). ${ }^{9}$ Při vytváření a formulování našich myšlenek u nás dochází ke kooperaci logických operací považovaných za projev racionality a toho, co lze nazvat operativní imaginací, tedy schopností vidět něco jako něco jiného. Právě tato kooperace se odehrává v metafoře. Metafora je tudíž mechanismus, pomocí kterého jsou vytvářeny nové významy, a který pracuje tak, že pomáhá chápat jednu věc z hlediska jiné věci (Lakoff a Johnson 2002: 15, 214). ${ }^{10}$ Metafory

\footnotetext{
${ }^{7}$ Jev je to, čím se sama věc nabízí našemu vnímání. Fenomén je jev uchopitelný aktem našeho vnímání a držený v mysli jako jeho korelát (Blecha 2007: 92-94).

${ }^{8}$ Korespondenční teorie pravdy ve zkratce říká, že pravda je to, když existuje soulad a shoda mezi poznáním a skutečností, tedy když spolu poznání a skutečnost korespondují.

${ }_{9}^{9}$ Diskurzivní strukturou mám na mysli určitá pravidla ovlivňující diskurz (Drulák 2009: 59). Diskurz je možné chápat jako soubor výpovědí a pravidla jejich tvorby (Foucault 2016: 45).

10 To mohou metafory dělat několika způsoby, z nichž pro studium narativů jsou nejdůležitější následující dva. První způsob je skrze strukturní metafory, které fungují tak, že "[...] jeden pojem je metaforicky strukturován na základě druhého pojmu" (Lakoff a Johnson 2002: 26). Typicky je pak pojem, který je strukturován, méně konkrétní (abstraktní či imaginativní), kdežto pojem, který strukturuje, je více konkrétní a vyhraněný, tedy empirický (Lakoff a Johnson 2002: 128; Stulík 2015: 98-99). Drulák (2008: 128) proto zavádí pojmy zdrojová a cílová oblast: pro porozumění cílové oblasti používáme naše povědomí o oblasti zdrojové. Druhý způsob je pomocí orientačních metafor, které „[...] organizuj[í] celý systém pojmů, a to všechny vůči sobě navzájem" (Lakoff a Johnson 2002: 128). Tyto metafory mohou organizovat časoprostor i hodnoty (srov. Pavelka 1982: 63-90). Jednotlivé metaforické pojmy spolu souvisí a tvoří koherentní systém, ve kterém jsou metafory $\mathrm{v}$ tzv. subkategorizační relaci. Zjednodušeně řečeno, $\mathrm{z}$ jednotlivých metaforických pojmů vyplývá jako důsledek jiná, podřazená metafora.
} 
v narativu fungují tak, že některé aspekty příběhu zvýrazní, zatímco jiné upozadí (Lakoff a Johnson 2002: 175). Mají tvar NĚCO JE NĚCO, např. „Č́na je zachránce“, a mohou být v textu přítomny explicitně, avšak daleko častěji implicitně, např. v opakovaném vyjádření ve smyslu „Č́na nám pomohla, jinak bychom byli ztraceni“. Dohromady metafory v narativu tvoří koherentní systém přenesených významů, díky kterému je možné měnit a posouvat významy promluv a tím modifikovat smysl vyprávěného příběhu.

Narativ či narace je způsob, jakým je artikulován čas (Ricoeur 2000: 88). Metaforická řeč dává člověku význam teprve tím, že je vyjádřena v příběhu, kde je čas samozřejmě klíčovým elementem, protože příběh se skládá z temporalizovaných událostí. I v př́ípadě, že aktér sděluje pouze strohá fakta, pro lepší porozumění je vhodné je uspořádat do narativní konfigurace (Hušek 2003: 19), tedy vytvořit z nich př́běh.11

Základním stavebním kamenem teorie narativu je strukturalistická konceptualizace Seymoura Chatmana, podle kterého se narativ skládá ze dvou částí: příběhu a diskurzu. Příběh je řetězcem událostí, ve kterém figurují tzv. existenty, tedy určité postavy a prostředí. Diskurs je pak způsob, jakým je př́běh zobrazen (Chatman 2008: 18). Takto strukturalisticky uchopený narativ může být vhodný pro analýzu příběhu samotného, ale neumožňuje nám uchopit vyprávění jako sociální akt a interpretovat jej v politologické perspektivě. Postrádá totiž klíčový element, kterým je lidský čtenář neboli horizont rozumění toho, kdo narativ přijímá. Z tohoto důvodu se jako vhodný jeví integrativní model vyprávění Paula Ricoeura. Ten chápe narativ či naraci jako tř́fázový proces: na začátku stojí prefigurace dané oblasti, která prochází textovou konfigurací jako prostředkem k závěrečné refiguraci v recepci narativu (Ricoeur 2000: 89).

Tyto fáze Ricoeur chápe jako dimenze ztvárnění světa neboli trojí mimésis. ${ }^{12}$ Tři mimésis nelze oddělit, jsou to vzájemně na sobě závislé a v hermeneutické spirále provázané aspekty narativu. Mimésis I vypovídá o tom, jak vypravěč narativu rozumí světu. Je to vypravěčovo (před)porozumění neboli komplexní ontologická a normativní koncepce světa, která kulminuje v určitou (byt' implicitně vyjádřenou) teorii jednotlivých pojmů. Tyto pojmy můžeme chápat jako základní body narativu. Vypráví-li politik např. o Číně, právě jeho konceptualizace Číny je první mimezí. Díky ní pak může proces pokračovat ve vznik mimésis II, kterou je dějová zápletka. Ta je ústředním a nejdůležitějším prvkem vyprávění. Je „kloubem“ mezi mimesis I a II, protože spojuje jednotlivé body narativu a dává je tak do určitého vztahu. Říká že, proč a jak se něco událo. Jejím smyslem je „konstitutivní konfigurace, kterou se konstruuje zápletka“ (Ricoeur 2000: 89). Proces je následně završen mimésis III, ve které vstupuje do hry osoba čtenáře

\footnotetext{
${ }^{11}$ Samozřejmě ne vždy jsou fakta narativizována. Následující analýza ukáže, jaké jevy narativizovány byly a jaké byly pouze metaforicky rámovány.

12 Ricoeur tento model představil v trojdílném díle Čas a vyprávění (2000), a za jeho srozumitelný převod do metodologické aplikace vděčím Hájekovi (2014).
} 
či diváka a jeho percepce toho, co je mu předkládáno. Zjednodušeně řečeno se jedná o prolínání a konfrontaci narativu se zkušenostmi, hodnotami ale i kognitivními schopnostmi toho, kdo narativ čte nebo poslouchá (Hájek 2014: 176-177). ${ }^{13}$ Celkově lze model shrnout tak, že se jedná o pohyb „od mimésis I k mimésis III na základě mimésis II“ neboli pohyb od „prefigurovaného času, který se prostřednictvím konfigurovaného času stává časem refigurovaným“" (Ricoeur 2000: 89-90).

Vyprávění tedy není nikdy pouhým transferem faktů. Vypravěč v něm na základě svého předporozumění světu uchopí nějaký objekt (např. událost), který narativně konfiguruje a ten, komu jej předává, si jej poskládá (refiguruje) podle vlastní percepce.

Diagram 1. Ricoeurův integrativní model narativu

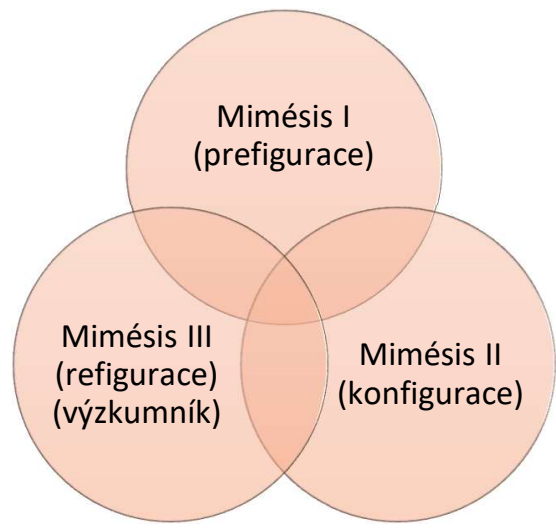

Zdroj: vlastní zpracování na základě Ricoeur (2000) a Hájek (2014).

\section{Zahraničněpolitický narativ}

Zahraničněpolitický narativ lze pojmout jako svazek několika prvků, které spolu určitým způsobem souvisí nebo na sebe alespoň odkazují. Základními strukturálními prvky jsou výše popsané pojmy metafora a narativ. Některé další prvky je nutno přidat a některá z nich se odvíjí od aplikované teorie mezinárodních vztahů.

$\mathrm{Na}$ počátku je určitá událost nebo informace sdělovaná nebo vyprávěná konkrétním aktérem. Podle Labova se narativ odvíjí od informace, která není všední, typická pro každodennost a je sdělitelná (Pope 2017: 56; srov. Labov 2006). ${ }^{14}$ Zatímco realismus chápe události jako fakt, podle konstruktivismu jednotlivé události nemluví sami za sebe. Jejich domnělé lekce jsou produktem interpretace politického aktéra (Krebs 2015: 810). Tento aktér není izolovaný, ale naopak jedná v určitém mocenském poli, ve kterém interaguje.

\footnotetext{
13 Dochází tedy k tomu, co hermeneutika nazývá splýváním horizontů (Gadamer 2010: 320-326).

14 Př́běhy zahrnuté v narativech jsou inspirovány skutečnými událostmi a tradicemi např. podle Fyyaze (2015: 65).
} 
Podle zvolené teorie lze dále přemýšlet nad momentem, kdy zahraničněpolitický narativ vzniká. Podle realistické teorie strategického narativu aktér stvoří př́iběh v rámci určité strategicky motivované politické akce. Nerozporuje přitom nutně další „mezifáze“ vzniku narativu, ale ve výzkumu s nimi nepracuje. Oproti tomu konstruktivismus rozebírá další elementy, jako jsou kulturní hodnoty aktéra odrážející se v diskurzu. Vliv má také to, co je považováno za pravdu a to, jak je vnímán svět (jak je mu rozuměno).

Zahraničněpolitický narativ pak konstruuje řadu důležitých jsoucen: identitu, historii, ideologii, kulturu, zahraniční politiku a mnohé další. Vytváří či udržuje určitý pohled na věc (Cheema-Shamil 2017: 136). Dává tím na počátku stojícím událostem či informacím význam. Reprezentuje určitý proces, ve kterém je posloupnost událostí vřazena do př́běhu v souladu s určitou ideologií. Tento př́iběh či tato reprezentace slouží k poskytnutí vysvětlení nebo ospravedlnění konkrétního jevu (Feisal-Hassan 2012: 1). Formuje přesvědčení, které v důsledku ovlivňuje politická rozhodnutí (Buzan a Hansen 2009: 198).

To vše jsou prvky zahraničněpolitického narativu. Diagram č. 1 (níže) znázorňuje souvislosti mezi nimi. Plná linka znamená vztahy mezi prvky optikou konstruktivismu, přerušovaná linka značí optiku konceptu strategického narativu. Tato práce sleduje konstruktivistickou linku, ale neodmítá zahrnutí realistického úhlu pohledu. Podstatné je, že zahraničněpolitický narativ se objevuje nebo je využíván v nějakém segmentu zahraniční politiky. Jeho klíčovou bytností je, že je komunikací. Sděluje a reprodukuje. Vypravěč do něj vkládá svůj pohled na svět (na zahraniční entity) a ohýbá jej podle svých zájmů (Slačálek 2009: 147), záměrů, tužeb, strategií či diskurzu a jeho limitů. Proto mohl Campbell přijít s jednou z nejdůležitějších prací na poli výzkumu politických narativů, ve které zkoumal konstruování nepř́tele v zahraniční politice USA (Campbell 1999).15 Narativ však může být $\mathrm{v}$ komunikaci konstruovaný záměrně i jaksi mimovolně (podle zákona o nezamýšleném účinku nebo zkrátka nekontrolovaně bez záměru vypravěče). Pokud je konstrukce narativu záměrná, můžeme hovořit o strategickém narativu (Miskimmon, O'Loughlin a Roselle 2017). Ale i pokud je nezáměrná, stále funguje tak, že svá sdělení rámuje určitým symbolem, čímž předkládá určitý výklad světa za současného zakrytí výkladů alternativních.

Tato studie bude identifikovat narativy v relativně malém výseku zahraniční politiky, ve vybraných ideových prostředcích, kterými jsou mediální výstupy daných aktérů ( $v$ žádném př́padě tedy nepojednává o zahraniční politice státu jako celku). Na tomto místě je tedy nejprve potřeba definovat zahraniční politiku. Kromě interakce státních aktérů je pro tuto studii důležitá inkluze „vnitřni“ a „vnějši“" politické arény: „[...] tvůrci politiky se pohybují na rozhraní dvou světů - vnitřní politiky státu a vnějšího prostředí. Jejich úkol spočívá ve zprostředkování mezi těmito světy“ (Druláková a Drulák

\footnotetext{
15 Přesto, že Campbell striktně nesouhlasil s Wendtovou epistemologií a poznání mezinárodních vztahů vnímal jako svého druhu další konstrukt (Campbell 1998: 25).
} 
2007: 11, cit. dle Evans a Newnham 1998). Odpovídá tomu Buzanův přístup, podle kterého zkrátka vnitřní a zahraniční politiku nelze zcela oddělit, naopak je mezi nimi vzájemný konstitutivní vztah (Buzan 1991: 60). Přesně toto podtrhuje Rittberger (2004: 24) když tvrdí, že normy aplikované v domácí politice se analogicky přenáší do politiky zahraniční a vice versa. Z tohoto pojetí vyplývá, že zahraničněpolitické narativy lze jednoznačně identifikovat i vprojevech, které jsou primárně určeny pro domácí publikum.

Diagram 1. prvky narativu

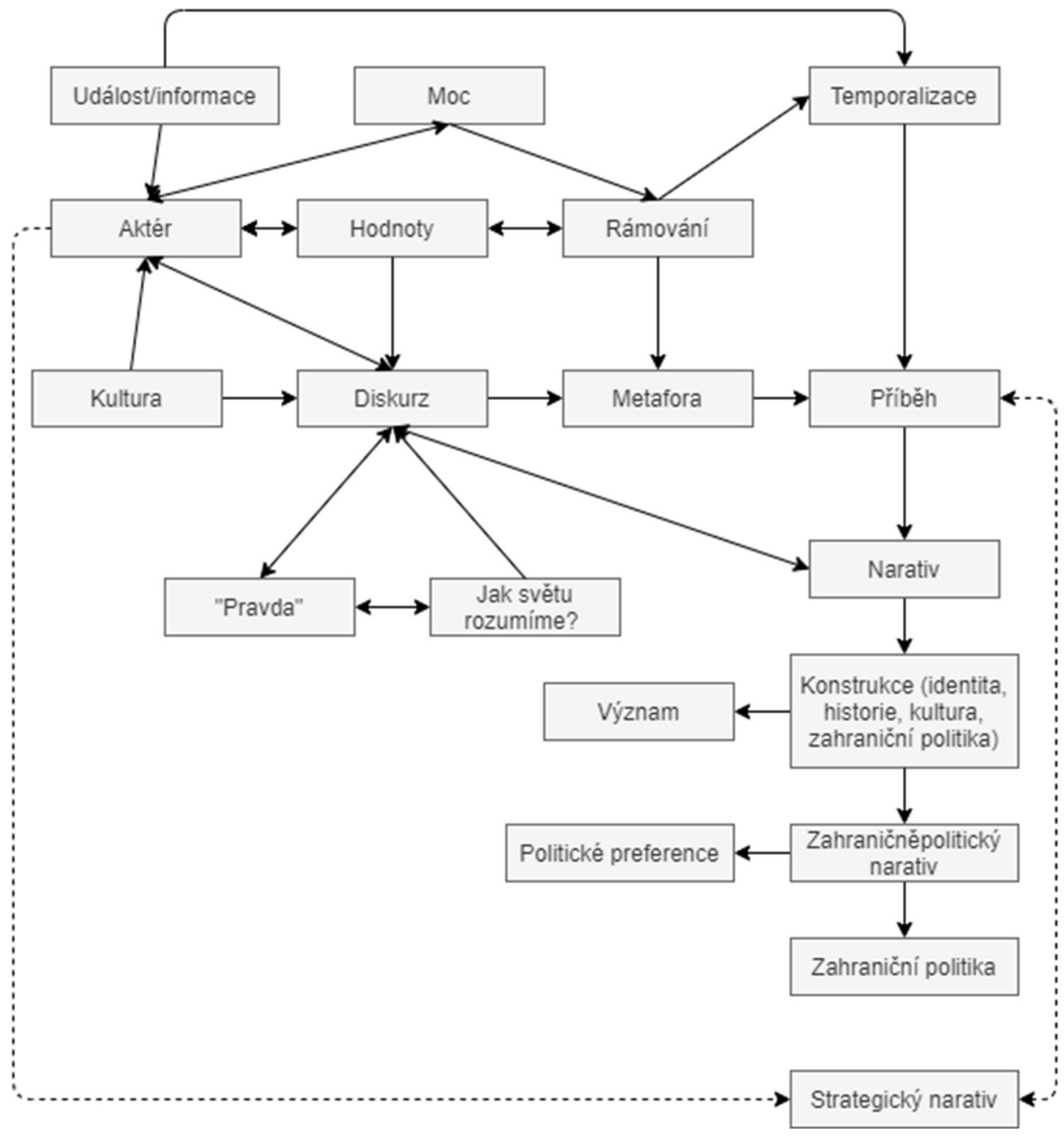

Zdroj: Autor.

Pro účely této studie provedu redukci výroků, kterými se budu zabývat: detailně zkoumány budou všechny promluvy, ve kterých zkoumaní aktéři alespoň jednou zmínili zahraniční entitu ve formě státu. ${ }^{16}$ Operacionalizace zahraničněpolitického narativu je tak

\footnotetext{
${ }^{16}$ Důvod této redukce je následující: aby bylo možné provést obsahovou analýzu, není třeba zkoumat a detailně čist všechny projevy zkoumaných aktérů. Ve vztahu k výzkumné otázce jsou relevantní pouze ty výroky, které zmiňují některou zahraniční entitu.
} 
logicky široká: jedná se o promluvu o zahraničněpolitické státní entitě; v této promluvě lze identifikovat trojí mimetickou strukturu, skrze kterou je v život uveden prríběh, který pomocí metafor komunikuje zahraničněpolitický obsah, a který tudíž působí jako jeden z faktorů ovlivňujících podobu zahraniční politiky.

\section{Použité metody výzkumu a jejich provázanost: jak zkoumat narativ}

V odpovědi na otázku, jak lze zahraničněpolitický narativ zkoumat, budu vycházet z Hájkovo vypracování postupu narativní analýzy (Hájek 2014: 179-184), který budu kombinovat s hermeneutickou analýzou metafor v diskurzu v návaznosti na strojově provedenou kvalitativní obsahovou analýzu (CAQDAS). Tuto kombinaci metod představuji jako jednu koherentní metodu: narativní analýzu metafor.

\subsection{První fáze: kódování empirického korpusu a studium významů}

Empirický korpus pro tuto studii je tvořen souborem dat vytvořených jejich stažením z veřejně dostupných internetových zdrojů na základě vstupních parametrů, tedy definováním zkoumaného období a aktérů. Konkrétním zdrojem dat jsou sociální sítě facebook a twitter (staženo pomocí platformy fanpagekarma), parlamentní stenoprotokoly, webové stránky zkoumaných aktérů a konečně všechna tištěná a internetová zpravodajská média (staženo pomocí platformy ANOPRESS). Celý korpus je tvořen 4082230 znaky a pro potřebu další analýzy byl převeden do software MAXQDA18.

Po sestavení korpusu byla provedena úvodní selekce dat. Připomínám, že tato studie se zajímá jenom o přímá vyjádření zkoumaných aktérů o zahraničí. Nejprve byla strojově vyhledána klíčová lemmata všech zemí světa (např. -ČíN- pro Čínu, -ITAL- pro Itálii atd.). Všechna tato lemmata byla spolu s odstavcem jejich výskytu označena speciálními kódy. ${ }^{17}$ Vznikly tedy kódy Čína, Itálie atd. (celkem 30 kódů). Další selekce byla již ruční. Byly odstraněny všechny výskyty kódů, které neodpovídaly smyslu hledaného výrazu (např. slovo vitalita taktéž obsahuje -ITAL-) a také výskyty, kde se nejednalo o přímou řeč zkoumaného aktéra. Dále byly odsunuty stranou výskyty, kde byla daná země zmiňována pouze jako součást dlouhého seznamu zemí a nebylo objeveno žádné tvrzení o těchto zemích (vyjádření ve smyslu „opatření se týkají zemí $\mathrm{X}, \mathrm{Y}, \mathrm{Z}$ “, ovšem bez udání důvodů nebo jiného významu). Poslední selekce se týká sledovaného kontextu. Byly odfiltrovány všechny promluvy, které nebyly vztaženy ke krizové situaci způsobené pandemií COVID-19.18

\footnotetext{
17 Věta výskytu lemmatu a tři předcházející a následující věty.

18 V tomto kroku bylo však odfiltrováno relativně málo výskytů, protože většina promluv se naopak týkala sledovaného kontextu. Přesto z analýzy vypadly tři země: Sýrie, Turecko a Řecko. Tyto země měly v celém
} 
Všechny kódy se vyskytují ve specifickém kontextu, na který jsou navázány. Aktéři ve svých projevech o dané zemi něco sdělují. Otevřeným kódováním proto vznikly kategorie, které odrážejí významový obsah odstavce (viz Stulík a Krčál 2019: 4). Příkladem je kategorie Poděkování Číně, do které byly zařazeny všechny projevy, ve kterých byl Číně vzdáván dík.

Zde je vhodné zapojit kvantitativní rozměr. Budou spočítány výroky, které z úst zkoumaných aktérů tematizovaly jednotlivé země. Už v úvodu analýzy tak bude možné říci, o jakých zemích se často mluvilo a jakým zemím se bude věnovat zbytek studie. Navíc bude možné si s další interpretací pomoci jistým zjednodušením. $\mathrm{K}$ tomu, aby kategorie byly lépe analyticky uchopitelné, budou všechny roztříděny do tří segmentů podle toho, zda je možné významový obsah daných výroků chápat jako pozitivní, negativní nebo ryze neutrální. ${ }^{19}$

Následně je třeba uspořádat strukturu kódů a připravit pole pro interpretaci. K tomu slouží vytvoření kontextuálních metafor. Je zde důležité identifikovat sémantickou tenzi, která vyplývá z posunu v operační oblasti (Charterise-Black 2004: 35). To se odvíjí od zvýraznění relevantních pojmů a vazeb mezi nimi. Jde tedy o to zjistit, jak na sebe pojmy odkazují, tedy identifikovat jejich kontexty (Stulík 2013: 43, 2016: 68-69). Je nutné určit hierarchii metaforických pojmů, a proto je následně vytvořeno schéma souvislostí mezi pojmy, které slouží k identifikaci kontextuálních vazeb. Soubor vyskytujících se a výzkumníkem zaznamenaných metafor tvoří tzv. množinu metafor pojímanou jako diskurz (Fridmanová 2005: 195).

\subsection{Druhá fáze: narativní analýza}

Postup analýzy je zprvu20 obrácený k postupu, jaký prezentoval Ricoeur v mimetickém procesu. První krok, refigurace v rámci mimésis III, se zabývá recepcí a interpretací narativu u čtenáře či posluchače. Jak tuto recepci uchopit? V narativní analýze je čtenářem výzkumník. Tento výzkumník text vnímá optikou zvolené teorie a vlastního hodnotového rámce. Tím, že jsem výše specifikoval politickou teorii narativu a pojednal o vlastním přístupu k celému zkoumanému tématu, jsem zároveň vymezil mimésis III zkoumaných narativů: refiguruji je jako narativní metaforickou komunikaci v určité dimenzi zahraniční

\footnotetext{
korpusu silnější zastoupení pouze kvůli několika dnům, ve kterých se intenzivně ve všech sledovaných zdrojích řešila migrační krize, a všechny promluvy o těchto zemí se týkaly pouze tohoto tématu. Jejich setrvání v analýze by tak způsobovalo pouze zmatení výstupů.

${ }^{19} \mathrm{~V}$ pozitivním výroku se aktér vyjadřuje o dané zemi pochvalně nebo optimisticky a často rámuje tuto zemi jako úspěšnou, pomáhající nebo bezpečnou. V negativním výroku je daná země naopak kritizována za svoji neschopnost, nebezpečnost, kritickou a nezvládnutou situaci atp. Neutrální výroky bez dalšího kontextu shrnují fakta o dané zemi a není možné z nich jasně určit další hodnoty.

${ }^{20}$ Po provedení analýzy je „poskládán“ zpět do původní posloupnosti (viz interpretce v kapitole 5.1.2).
} 
politiky, která má za cíl předat zjednodušený obraz reality, ve kterém jsou určité prvky zvýrazněny, zatímco ostatní mohou být potlačeny.

Druhý krok, konfigurace narativu neboli transformace vypravěčova předporozumění do vyprávěného narativu v rámci mimésis II se zabývá zápletkou tohoto narativu. Jak upozorňuje Hájek, na tomto místě bude třeba se ptát na následující otázky: „a) jakým způsobem je príběh spjat sosobou vypravěče [...]?; (b) jakým způsobem je vyprávění orientováno na posluchače a sjakými důsledky pro př́iběh?; (c) jak vypravěči konstruují zápletku př́běhu, aby dávala v daném kontextu smysl?" (Hájek 2014: 181-182).

Třetí krok, prefigurace narativu v rámci mimésis I, zjišt'uje vypravěčovo předporozumění světu. To lze podle Ricoeura (2007: 352) vysledovat analýzou narativní identity odvozené ze zkoumaných (metaforických) promluv. Lze zde klást otázky: „[a] jakého druhu jsou aktéŕi př́iběhu (jednotlivci, [...] organizace), jaké vztahy vůči sobě mají, $v$ čem spočívá jejich aktérství apod.; [b] jakje symbolicky zprostředkovanéjejich jednání (jak spolu aktéri komunikují, jaké kulturní hodnoty a normy ovlivňují jejich jednání) a jakou temporální dynamiku má ve vyprávění pojednávané dění (následnost a zlomy v dění, „bezčasí" nebo naopak zhuštěnost událostí [...]“; a c) jaká je „situace, v níž se vyprávění odehrává" (Hájek 2014: 183-184).

\section{5. Čína a ti druzí v narativní analýze metafor}

Po představení teoretického zázemí a metodologie studie je možné nyní postupovat směrem k samotné analýze zahraničněpolitických narativů. Numerické zastoupení výroků o jednotlivých zemích ukazuje graf č. 1. Suverénně nejvíce výroků bylo proneseno o Číně (194 výskytů). Zhruba třikrát méně výroků se týkalo Evropské unie (68), Itálie (57) a Ukrajiny (52). Řádově méně pak bylo zmiňováno Německo, Španělsko, Rakousko a Slovensko. Z ostatních států stojí za zmínku ještě Francie, ale ta byla zmíněna pouze ve třinácti výrocích a ostatní země již byly zmíněny v méně než deseti př́ípadech.

Graf 1. Počet výskytů

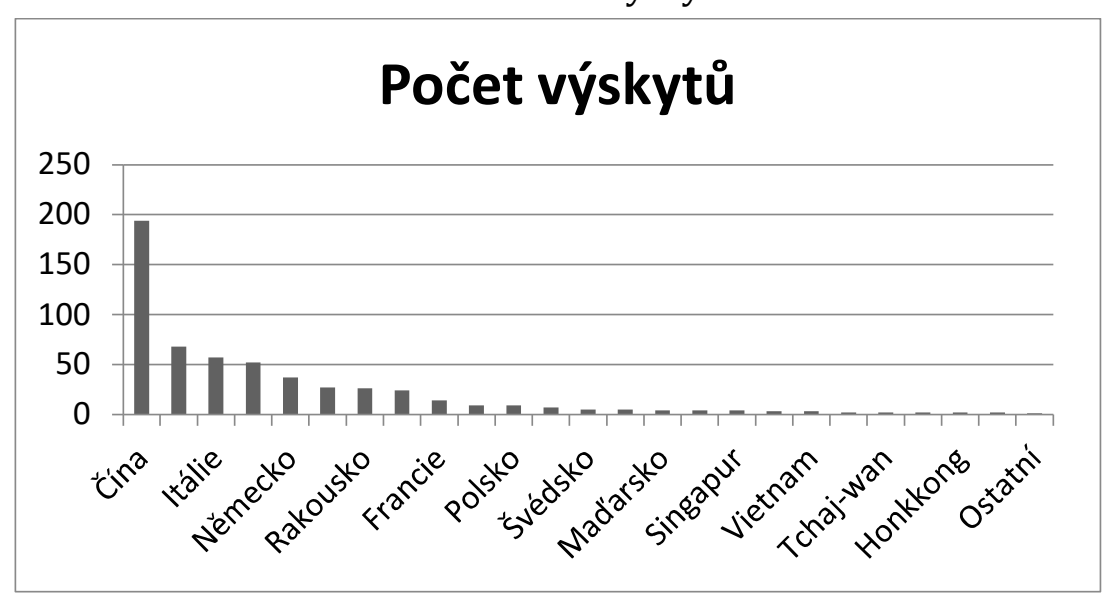

Zdroj: autor. 
Zkoumaní aktéři o těchto zemích podle předpokladu hovořili ve specifických kontextech a analýzou obsahu jejich promluv byla určena řada subkategorií odrážející jejich metaforický význam (viz výše). Graf č. 2 ukazuje skladbu výroků podle toho, zda byli vůči dané zemi pozitivní, negativní či neutrální (z důvodu přehlednosti se tato vizualizace již omezuje pouze na země s větším výskytem výroků). Je vidět, že výroky o Číně byli v přesvědčivé většině pozitivní. V případě Ukrajiny a Slovenska drtivě převažuje neutralita a v př́ípadě Španělska a Francie převažují vyjádření negativní. U ostatních zemí jsou pozitivní vyjádření v menšině, ale kvantifikovaný rozdíl mezi negativními a neutrálními výroky není př́liš výrazný.

Faktem je, že ve sledovaném období byla situace co do počtu výskytu SARS-CoV2 na počet obyvatel ve všech zmíněných zemích horší než v ČR. Je tedy logické, že politici takto o situaci referovali. Nicméně výroky se netýkají pouze počtu nakažených - tyto výroky byly vždy samostatně kódovány a jsou zahrnuty v subkategorizačním schématu. Negativní, pozitivní i neutrální výroky se týkaly např. otázce spolupráce, identity, charakteru a obecně postoje $\mathrm{k}$ dané zemi.

Graf 2. Hodnotové segmenty pro jednotlivé země

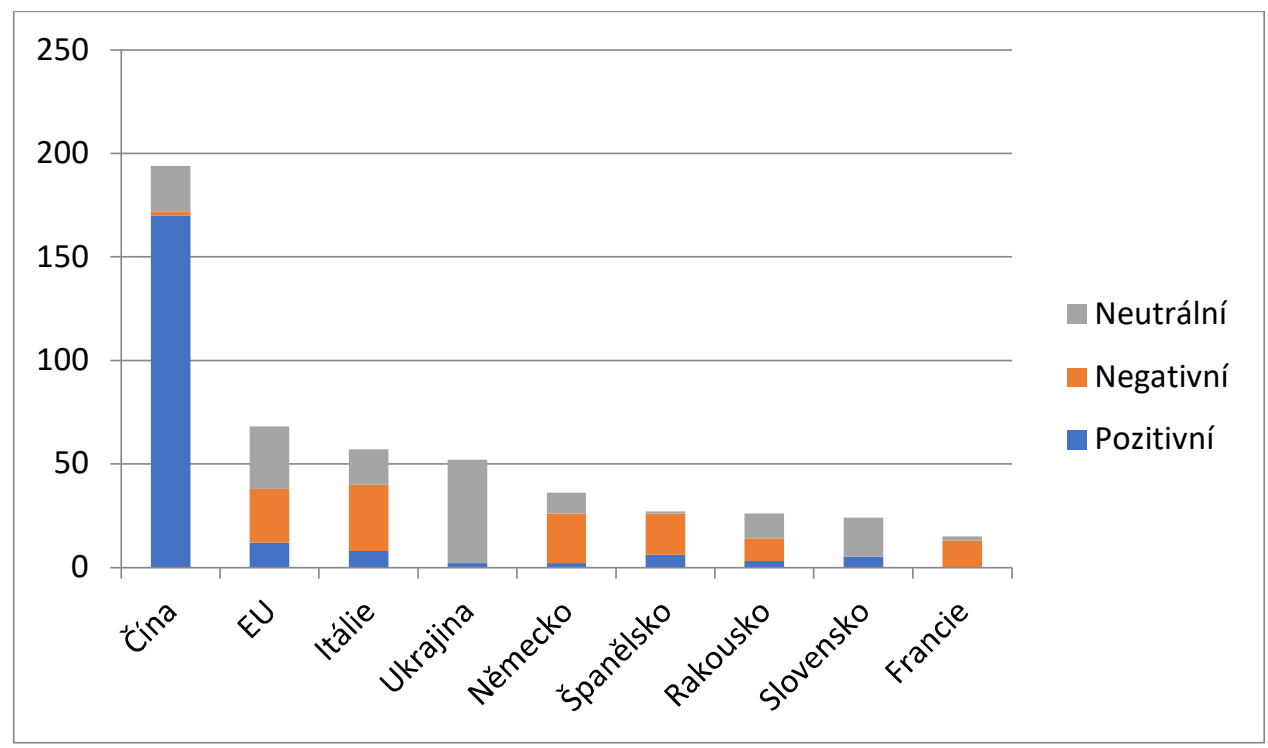

Zdroj: autor.

Byt' neexistuje žádné vodítko, jak určit dostatečný vzorek dat, který by byl reprezentativní a měl tudíž dostatečnou vypovídací hodnotu, intuitivně je cítit, že počet zaznamenaných kódů pro všechny země kromě Číny je pro sestavení narativu př́liš nízký. V této fázi je tedy jasné, že se nepodaří rekonstruovat narativ o evropských zemích a interpretace dat bude končit u některých zemí stanovením kontextuálních metafor a u jiných zemí dokonce pouze zjištěním kategorií na základě CAQDAS. ${ }^{21}$ To ovšem nutně neznamená, že

\footnotetext{
${ }^{21}$ Komparativní perspektiva by byla taktéž málo přesvědčivá z důvodu nedostatku komparovatelných dat.
} 
tato data nelze interpretovat. Zkoumaní aktéři nám „poskytují“ data tím, že o něčem hovoří, stejně jako tím, že o něčem nehovoří. Jedná se o variantu oné moci tzv. nerozhodování, upozadění tématu či objektu, o němž by se za jiných okolností mohlo hovořit hojně (Bachrach-Baratz 1962; srov. Debnam 1975).

Nyní je vhodné podívat se blíže na konkrétní kategorie. Z této fáze je možné vypustit Ukrajinu a Slovensko, kde jasně převažují neutrální vyjádření. V př́ípadě Slovenska se tyto výroky týkají oznámení o opatřeních platných v této zemi a v př́padě Ukrajiny se hovořilo zejména o letadle Ruslan převážejícím zdravotnický materiál. Kategorie u ostatních zemí a jejich početní zastoupení ukazuje tabulka č. 1.

Tabulka 1. kategorie podle jednotlivých zemí

\begin{tabular}{|c|c|c|c|c|c|}
\hline \multicolumn{2}{|l|}{ Čína } & V EU je boj & 1 & Spolupráce s Německem & 1 \\
\hline Neutrální & 27 & Kritika promigrační a zelené EU & 1 & \multirow{2}{*}{\multicolumn{2}{|c|}{$\underline{\text { Španělsko }}$}} \\
\hline Kritika čínských investic & 1 & Problematická EU & 1 & & \\
\hline Čínská pomoc & 58 & Neshoda s EU & 1 & Neutrální & 1 \\
\hline Čína jako jediná možnost & 22 & Lakomá EU & 1 & Ve Španělsku je horší situace & 12 \\
\hline Dodávky z Číny & 16 & Spící EU & 1 & Ve Španělsku je kritická situace & 5 \\
\hline Čínský úspěch & 12 & Nezodpovědní Evropané & 1 & Neschopné Španělsko & 1 \\
\hline Letecký most & 12 & Spolupráce s EU & 11 & Ekonomické problémy Španělska & 1 \\
\hline Pomoc do Číny & 9 & Obhajoba EU & 2 & Exponenciální růst nakažených & 1 \\
\hline Čína je důležitý partner & 8 & \multirow[b]{2}{*}{ Itálie } & & Pomoc Španělsku & 6 \\
\hline Dar z Číny & 8 & & & \multirow{2}{*}{\multicolumn{2}{|c|}{$\underline{\text { Rakousko }}$}} \\
\hline Poděkování Číně & 7 & Neutrální & 17 & & \\
\hline Čína jako jediná pomoc & 4 & V Itálii je kritická situace & 17 & Neutrální & 12 \\
\hline Čína je jistota & 2 & V Itálii je horší situace & 6 & V Rakousku je horší situace & 7 \\
\hline Potřebujeme Čínu & 2 & Odstrašující případ & 4 & Nebezpečné Rakousko & 3 \\
\hline Vhodné řešení & 2 & Nemocný Ital & 2 & Rizikové Rakousko & 1 \\
\hline Situace ve světě horší než v Číně & 1 & Itálie je riziko & 1 & Dodávky z Rakouska & 2 \\
\hline Čína je jediná schopná země & 1 & Italská skluzavka & 1 & Spolupráce s Rakouskem & 1 \\
\hline Dobré vztahy s Čínou jsou výhodné & 1 & Itálie je hlavní problém Evropy & 1 & \multirow{2}{*}{\multicolumn{2}{|c|}{ Francie }} \\
\hline Čína je v ohrožení & 1 & Podpora Itálie & 1 & & \\
\hline Omluva Číně & 1 & Pomoc Itálii & 7 & Neutrální & 2 \\
\hline \multirow{2}{*}{\multicolumn{2}{|c|}{$\underline{\mathbf{E U}}$}} & \multirow{2}{*}{\multicolumn{2}{|c|}{ Německo }} & Neschopná Francie & 1 \\
\hline & & & & Ve Francii je horší situace & 9 \\
\hline Neutrální & 32 & Neutrální & 10 & Exponenciální růst nakažených & 1 \\
\hline Horší situace v EU & 6 & V Německu je horší situace & 11 & & \\
\hline Neschopná EU & 3 & Nebezpečné Německo & 5 & & \\
\hline Nedostatek v EU & 2 & Německo je riziko & 4 & & \\
\hline Nepotřebná EU & 2 & Chybující Německo & 1 & & \\
\hline Nefunkční Evropa & 1 & Zvláštní přístup Německa & 1 & & \\
\hline EU musí platit & 1 & Neschopné Německo & 1 & & \\
\hline Pochybnosti vůči EU & 1 & Exponenciální růst nakažených & 1 & & \\
\hline Chybující EU & 1 & Pomoc od Německa & 1 & & \\
\hline
\end{tabular}

Zdroj: autor. 


\section{1 Čína}

\subsection{1 Čína v metaforách}

Jak již bylo zmíněno, v promluvách o Číně se negativní vyjádření objevuje v jednom jediném př́padě. Jde o kritiku nedostatečných čínských investic ze strany prezidenta Zemana (Zázvorka 2020). Dominantním typem vyjádření je takové, ve kterém je dodávání zdravotnického materiálu z Číny do ČR (a v menšině do dalších zemí, zejména do Itálie) chápáno jako pomoc. Jako př́klad uvedu dva příspěvky ministra vnitra Jana Hamáčka na sociálních sítích, které následovaly v rychlém sledu po sobě 20 . března: „Je to tady! Vykládáme 1,1 milionu respirátorů z Číny. Další dodávky respirátorů, roušek a jiného materiálu budou následovat“ (Hamáček 2020a); „Když potřebovali pomoc, pomohli jsme. Ted' pomáhají oni nám. Ochranné pomůcky právě dorazily do Česka“ (Hamáček 2020b). Pro tato vyjádření byl vytvořen kód ČÍNSKÁ POMOC.

Početně druhý nejvíce zastoupený kód byl nazván ČÍNA JAKO JEDINÁ MOŽNOST. Odkazuje k situaci, ve které je zajištění dodávek zdravotnického materiálu z Číny jediná možnost, protože ostatní cesty se ukazují jako pomalé, neefektivní nebo co do počtu nedostačující. Ještě jednou Hamáček: „Během pár dní jsme zajistili nouzové zásobování z Číny, protože jiná kapacita nebyla. Kdybychom to neudělali, už minulý týden nebylo nic..." (Hamáček 2020c).

Podobná vyjádření, jen s méně aditivy, jsou kódována jako DODÁVKY Z ČíNY a obsahují jednoduché odkazy k zásobování ČR a dalších zemí ze strany ČLR. Pod kódem ČÍNSKÝ ÚSPĚCH se nachází řada vyjádření o úspěšnosti čínského režimu v boji s COVID19, jako např. následující: „Z Číny si myslím, že ted' není ani ten zásadní problém. Skutečně tam ta situace se zlepšuje. Ten problém je z Itálie" (Vojtěch 2020).

Zajímavým kódem je dále metafora LETECKÝ MOST: „Ministerstvo dopravy ve spolupráci s ostatními rezorty zahajuje letecký most s Čínou“ (Havlíček 2020a). Tato metafora byla používána pro letecké dodávky materiálu z Číny, nicméně její volba je zajímavá kvůli zdrojové oblasti její zkušenosti. Jedná se o válečnou metaforu. Evokuje vzpomínku na poválečnou blokádu západního Berlína. ČR jako by byla v neproniknutelném obležení bez možnosti postarat se o sebe sama a Čína ji tímto jediným mostem zachraňovala z nejhoršího.

Dále se objevuje několik výskytů kódu POMOC DO ČÍNY odkazujících na promluvy o pomoci české vlády Číně zejména v prvních březnových dnech. Kód DAR Z ČíNY je pro (doslovné) rámování dodávek zakoupených v Číně jako daru: „V Šanghaji na letišti čekají dary z měst a provincií, které už ted' prevyšují to, co jsme jim poslali my... "(Hamáček 2020d). Přesvědčení, že je Čína důležitá země pro Českou republiku, a proto je výhodné se na ni obracet, a dokonce je vhodné mít s ní dobré vztahy, vyjadřuje kód ČÍNA JE DŮLEŽITÝ PARTNER. Objevují se tvrzení jako např. následující: „A kdo má ty kontakty v Číně? Přes koho to pan Hamáček řeší. Ano, máme tam kontakty, chválabohu, že tam máme kontakty. A 
dnes je to jediná země, která dodává do celého světa“ (Vláda České republiky 2020a). Dále se celkem sedmkrát objevuje přímé adresné poděkování Číně. Následující citace vystihuje jeho apel: „[...] já jsem dnes volal čínskému velvyslanci. Já jsem ho poprosil, zda by nám nemohla čínská vláda pomoci, a zda by nám nemohli půjčit nákladní civilní nebo nákladní vojenské letadlo, cokoliv, co by sem ten materiál dostalo co nejrychleji. Pan velvyslanec mi slíbil, že se obrátí na své nadřízené, a já doufám, že nám Čína pomůže. Každopádně stojí za to poděkovat, protože bez toho, jak se k nám chová čínská ambasáda v téhle krizové situaci, bychom to nezvládli. Děkuji“" (Vláda České republiky 2020b).

Jak ukazuje tabulka č. 1, ostatní kódy jsou již zastoupeny méně. ČíNA JAKO JEDINÁ POMOC je kód odkazující k situaci, ve které se Česká republika podle těchto vyjádření měla nacházet: mající jediného spojence $\mathrm{v}$ Číně, odkud jako $\mathrm{z}$ jediné země na světě přichází pomoc. Nejedná se přitom pouze o prezidenta ČR Zemana, který toto prohlásil zcela explicitně (Zeman 2020b). Podobná vyjádření zazněla od ministra vnitra Hamáčka: „Koneckonců těch slibovaných půl milionu respirátorů od resortu zdravotnictví je stále $v$ Rotterdamu. Takže kdyby tady nebyl ten letecký most z Číny, dávno už by respirátory a další ochranné prostředky došly" (Shabu 2020). Kód ČÍNA JE JISTOTA označil ta vyjádření, ve kterých je naznačeno, že zatímco se v otázce dodávek zdravotnického materiálu nelze spolehnout na domácí produkci ani jiné zahraniční dodavatele, Čína je partner, na kterého se lze spolehnout. Dokládají to některé tweety Jana Hamáčka, např. následující: „Jsem pro české ventilátory podpořit a jakmile budou hotové a vyzkoušené, klidně zruším ty objednávky z Číny, nebo je prodám někomu jinému..." (Hamáček 2020f).

Další kód s názvem ČíNA JE JEDINÁ SCHOPNÁ ZEMĚ oslavuje (ve vyjádření prezidenta Zemana) Čínu jako jedinou zemi, která byla schopna České republice zajistit dodávky do zdravotnictví (Právo 2020). Oproti tomu kód SITUACE VE SVĚTĚ HORŠÍ NEŽ V ČíNĚ popisuje vyjádření téměř přesně shodná s jeho názvem: vČíně se daří situaci zvládat, zatímco jinde ve světě je situace kritická.

Osamoceným výskytem je kód ČÍNA JE V OHROŽENÍ, který byl zaznamenán v projevu premiéra Babiše: „[...] minulou sobotu v Číně zaznamenali nárůst asi o padesát případů nákazy a vše přišlo ze zahraničí (Langová 2020). Jeden výskyt byl zaznamenán i u kódu VHODNÉ ŘEŠENÍ odkazujícímu k tomu, že v nastalé situaci bylo obrátit se na Čínu výhodné a efektivní. Posledním zaznamenaným kódem je OMLUVA ČÍNĚ. Premiér Babiš se vtomto př́padě omlouvá čínskému velvyslanci za mylné informace o dodávce zdravotnického materiálu (Vláda České republiky 2020a).

Výše zmíněné kódy lze podle obsahu rozdělit do tří skupin, v rámci kterých tyto kódy mají společný kontext a tím i smysl. ${ }^{22} \mathrm{~V}$ důsledku se totiž týkají společného aspektu, díky čemuž je možné hierarchizovat jejich vztah a určit kontextuální metaforu. Nejpočetnější skupina kódů23 dohromady tvoří metaforu ČíNA JE ZACHRÁNCE. Díky

\footnotetext{
${ }^{22}$ Samostatně stojí pouze kódy ČÍNA JE V OHROŽENÍ a OMLUVA ČÍNĚ.

23 ČÍNSKÁ POMOC, LETECKÝ MOST, PODĚKOVÁNÍ ČÍNĚ a ČÍNA JAKO JEDINNÁ POMOC.
} 
zdrojové (imaginativní) oblasti (záchrana) tato metafora vykresluje nebezpečnou situaci, ve které se nachází ČR a potažmo celý svět v důsledku pandemie COVID-19. Nedokážeme si pomoci sami a z obklíčení nám leteckým mostem a jako jediný pomáhá čínský zachránce. Za to je třeba mu poděkovat. Další kódy tvoří metaforu ČíNA JE PARTNER. ${ }^{24}$ Díky zdrojové oblasti (partnerství) se zde předkládá obraz vztahu Číny a ČR (marginálně též zbytku světa). Čína je vyobrazena jako jediný dodavatel zdravotnického materiálu a tento vztah je i obrácený, protože ČR poskytla Číně humanitární pomoc. Z Číny pak kromě dodávek putují i přímo dary, což partnerství posiluje. ČR totiž Čínu potřebuje a mít s ní dobré vztahy je výhodné a efektivní. Třetí skupina kódů tvoří metaforu ČínA JE DOBRÁ. ${ }^{25}$ Zdrojová oblast je zde normativně pozitivní percepce Číny, ve které se ukrývají pochvalná vyjádření o situaci v Číně a schopnostech ČLR jako státu. Čína je totiž v boji s nemocí COVID-19 úspěšná a je schopná situaci zvládnout. Nabízí jistotu, zatímco okolní svět je v těžkých potížích. Subkategorizační schéma těchto metafor vyjadřuje diagram č. 1.

Diagram 2. Subkategorizační schéma metafor o Číně

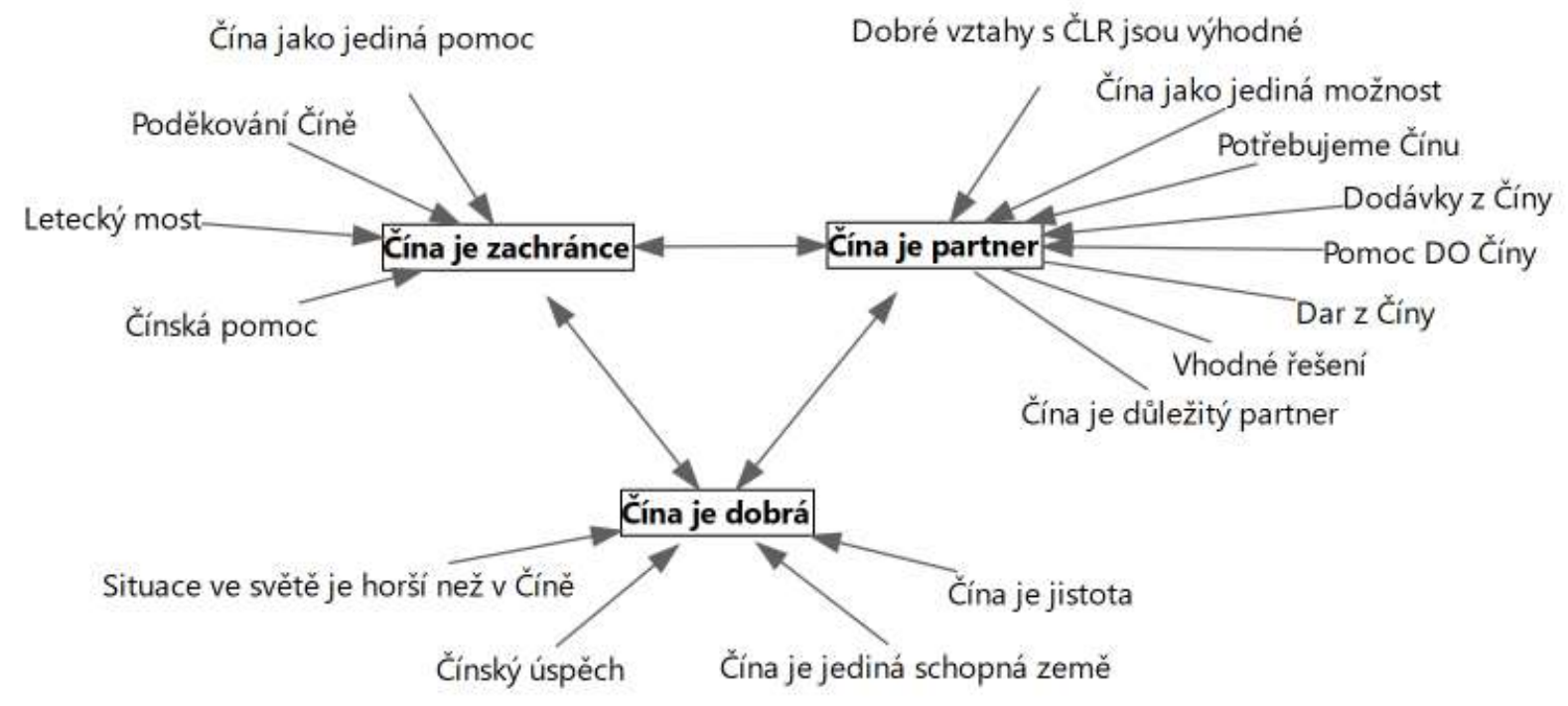

Zdroj: autor.

\subsection{2 Čína v narativu}

Jak bylo uvedeno v kapitole 3, narativ o Číně je třeba vnímat optikou mimetické struktury, tedy (1) prefigurace, (2) konfigurace a (3) refigurace. Prefigurace. Situace, ve které se př́běh odehrává, je bezprecedentní společenská, zejména zdravotnická krize. Zkoumaní aktéři v ní vystupují jako klíčové osoby zodpovědné jak za její řešení, tak také za její

\footnotetext{
24 ČÍNA JAKO JEDINÁ MOŽNOST, DODÁVKY Z ČÍNY, POMOC DO ČÍNY, ČÍNA JE DŮLEŽITÝ PARTNER, DAR Z ČÍNY, POTŘEBUJEME ČÍNU, VHODNÉ ŘEŠENÍ a DOBRÉ VZTAHY S ČÍNOU JSOU VÝHODNÉ.

25 ČÍNSKÝ ÚSPĚCH, ČÍNA JE JISTOTA, SITUACE VE SVĚTĚ JE HORŠÍ NEŽ V ČÍNĚ a ČÍNA JE JEDINÁ SCHOPNÁ ZEMĚ.
} 
vysvětlení svému publiku. Vyprávějí proto (mezi jinými) příběh, jehož hlavní „postavou“ je Čína. Čína je vykreslena jako úspěšná, schopná, partnerská a pomáhající země. Vedlejší roli v něm hraje Česká republika (okrajově pak další země), která je vděčným příjemcem čínské pomoci. Hlavními symboly vztahu mezi Čínou a Českou republikou jsou záchrana, partnerství a dobrota. Toto jsou pevné body narativu, které se v průběhu vyprávění nemění. Naopak temporální dynamika příběhu je velice klidná, neobjevují se zásadní zvraty (ve smyslu aporetických vyjádření) a vyprávění má jeden jasný vektor.

Konfigurace. Zkoumaní aktéři vyprávějí narativ o zahraniční mocnosti, se kterou nastavují konkrétní mezistátní vztahy. At' už jsou si toho při svém vyprávění vědomi či ne, právě toto je zásadní způsob, jakým je jejich narativ propojen s rolí, ve které operují. Vyprávění není určeno primárně čínskému publiku. Vzhledem k charakteru zkoumaných dat je narativ určen široké veřejnosti v ČR, což může mít kvůli tematickému přizpůsobení narativu situaci v ČR za důsledek (záměrný i nezáměrný) značné zjednodušení a zploštění toho, o čem je vyprávěno. Obojí se skutečně děje: příběh o Číně je až komicky plochý a je vztažen zejména k ČR (např. jak Čína pomáhá ČR).

A jak tedy vypadá zápletka? Vyprávěn je př́běh o Číně, která je zachráncem a partnerem. Když vypukla celosvětová zdravotnická krize a okolní státy tuto krizi nezvládaly, Čína jako jediná přišla na pomoc do krizové (téměř válečné) zóny, zachraňuje nás a za to jí patřri vděčnost. Vzhledem k tomu je na Čínu spolehnutí jako na spolehlivého a vhodného partnera, se kterým je výhodné mít dobré vztahy. Nejen že ji potřebujeme, ale jsme ochotni jí i pomoci, když bude potřebovat ona. Je to totiž dobrá a úspěšná země.

Refigurace. Pomocí metaforického narativu o Číně zkoumaní aktéři předkládají určitý konstrukt Číny. Ve své rétorice zvýrazňují pozitivní stránky Číny a jejich vztahu s touto zemí, zatímco nehovoří o negativních aspektech tohoto vztahu, čínského režimu jako takového nebo i aktuální situace ohledně pandemie COVID-19.

\subsection{Ostatní země v kategoriích}

Vytvořit kontextuální metafory bylo možné u EU, Itálie, Německa a Španělska. U Rakouska a Francie nebylo možné ani to. V jednotlivých př́padech popsaných níže bude okomentována proveditelnost interpretace dat.

\subsubsection{Evropská unie}

V promluvách o EU jednoznačně převažují neutrální vyjádření. Nejméně vyjádření je pozitivních, přičemž častým kódem je SPOLUPRÁCE. Aktéři v nich hovoří o potřebě spolupráce v rámci EU, včetně spolupráce s evropskými institucemi. Viz jedno z mnoha vyjádření ministra zahraničních věcí Petříčka: „Při jednání o aktuálním tématu pandemie COVID-19 jsme se shodli, že řešení nemůže být jen na národní úrovni, ale že jde o společný evropský a globální problém, kde bude třeba zapojit společné zdroje" (Petříček 2020a). Ve 
dvou případech se objevuje kód OBHAJOBA, ve kterém aktéři obhajují správnost postupu EU (např. Hamáček 2020; Nguyen 2020). Častěji je ovšem EU prezentována negativně. Především je v ní HORŠÍ SITUACE v souvislosti s COVID-19 než ve zbytku světa a je v ní NEDOSTATEK zdravotnického materiálu. Dále je EU NESCHOPNÁ, NEPOTŘEBNÁ, NEFUNKČNÍ, POMALÁ, CHYBUJÍCÍ, PROBLEMATICKÁ, SPÍCÍ, LAKOMÁ a dokonce PROMIGRAČNÍ A ZELENÁ (myšleno pejorativně). ${ }^{26}$ Zmiňme alespoň jeden konkrétní př́klad: „Chci upozornit, že na boj s COVID-19 nedává EU ani o korunu víc, než na kolik měly stát nárok už před pandemií. Schválených 30 mld. Kč, kvůli kterým média oslavují evropské instituce, nejsou peníze navíc. Jsou dávno naše“ (Babiš 2020). Spolupráce v EU navíc není samozřejmost: vjediném výskytu kódu EU MUSÍ PLATIT ministr Petříček požaduje koordinaci v letecké dopravě zaplatit z rozpočtu EU (Koutník 2020). Aktéři zmiňují, že v EU se mezi státy vede BOJ (PČR 2020) a je mezi nimi NESHODA (PČR 2020).

Spojením smyslů jednotlivých kategorií mohou vzniknout dvě kontextuální metafory. EU JE ŠPATNÁ a EU JE PARTNER. První zmíněná je normativní metafora zahrnující širokou variabilitu pejorativních kategorií. Druhá doslovně odpovídá svému názvu. Nicméně celková interpretace je nejasná, protože (odmyslíme-li na moment již zmíněnou nereprezentativnost počtu výskytů) přes konstrukci kontextuálních metafor stále převažují neutrální výroky.

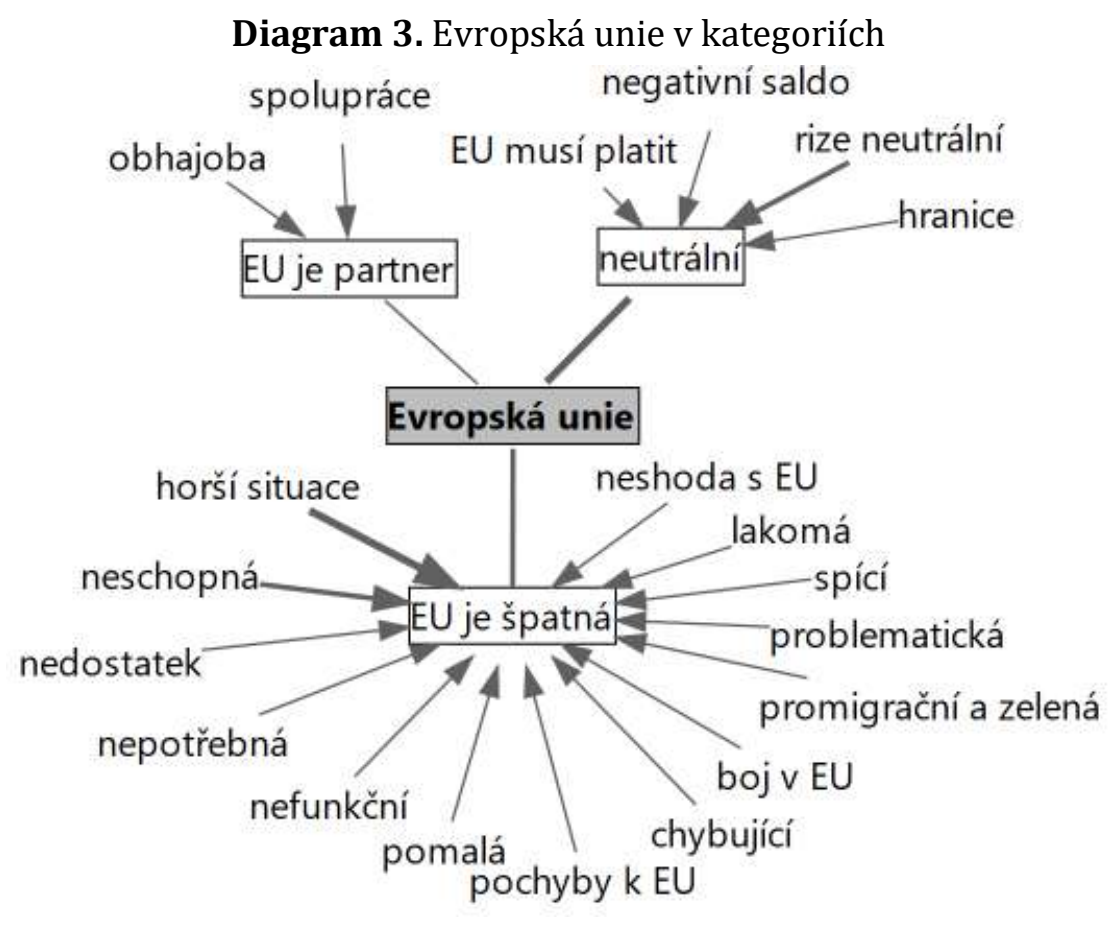

Zdroj: autor.

\footnotetext{
${ }^{26}$ Viz např. Vláda České republiky (2020c, 2020d), Babiš (2020b).
} 


\subsubsection{Itálie}

V př́ipadě Itálie jasně převažují negativní vyjádření. Nejčastěji je zmiňována zhoršená až kritická situace (v souvislosti s COVID-19) pod kódem KRITICKÁ SITUACE. V několika případech je Itálie považována za ODSTRAŠUJÍCí PŘÍPAD a RIZIKO. Jednou je dokonce označena za HLAVNÍ PROBLÉM EVROPY. Ve dvou případech aktéři tematizovali nemocné Italy na území ČR a lingvisticky zajímavý je kód ITALSKÁ SKLUZAVKA, ve kterém je přesně takto popsána rychle se zhoršující situace v této zemi. V několika promluvách aktéři hovoří o pomoci Itálii a vyjadřují jí podporu (kódy PODPORA a POMOC).

Kontextuálním propojením smyslů tak vznikají kontextuální metafory ITÁLIE JE V KRIZI a ITÁLIE JE POTŘEBNÁ. ${ }^{27}$ Neutrálních výroků však není málo, a tak ani v tomto případě nemůže být interpretace jednoznačná.

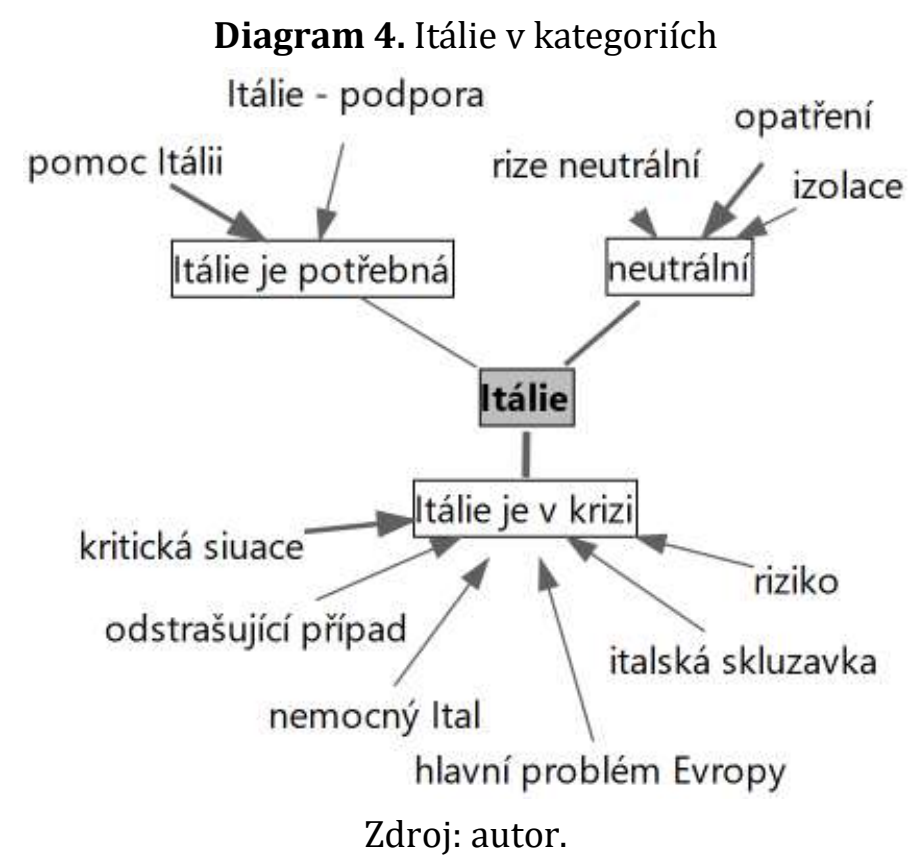

\subsubsection{Německo}

I v případě Německa převažuje negativum. Nejčastěji je komentována HORŠÍ SITUACE (v souvislosti s COVID-19) oproti jiným zemím. Německo je ale také označeno jako NEBEZPEČNÉ, NESCHOPNÉ, CHYBUJÍCÍ a jako RIZIKO. V pejorativním smyslu je komentován jeho ZVLÁŠTNÍ PŘÍSTUP k pandemii. Ojediněle se objevují kódy pozitivní percepce SPOLUPRÁCE a POMOC.

Vzniknuvší kontextuální metafory jsou NĚMECKO JE V KRIZI a NĚMECKO JE PARTNER, ovšem nesmíme zapomínat na početně nízký odstup od neutrálních vyjádření, což opět brání jasné interpretaci.

\footnotetext{
$27 \mathrm{~V}$ tom smyslu, že potřebuje pomoc (necessarius).
} 


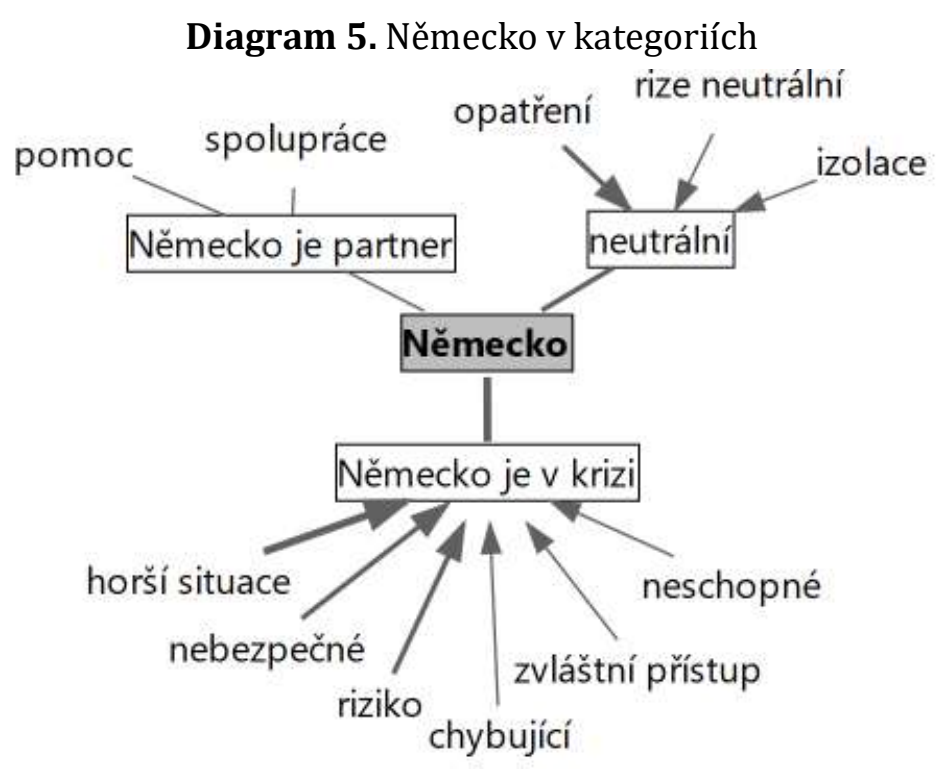

Zdroj: autor.

\subsection{4 Španělsko, Rakousko a Francie}

Negativní vyjádření převažují i v případě Španělska (tentokrát přesvědčivě). Nejvíce je zmíněna KRITICKÁ SITUACE a jedenkrát se objevuje označení Španělska za NESCHOPNÉ. Oproti tomu v několika případech je zmíněna potřeba Španělsku pomoci. Kontextuálními metaforami tak jsou ŠPANĚLSKO JE V KRIZI a ŠPANĚLSKO JE POTŘEBNÉ.

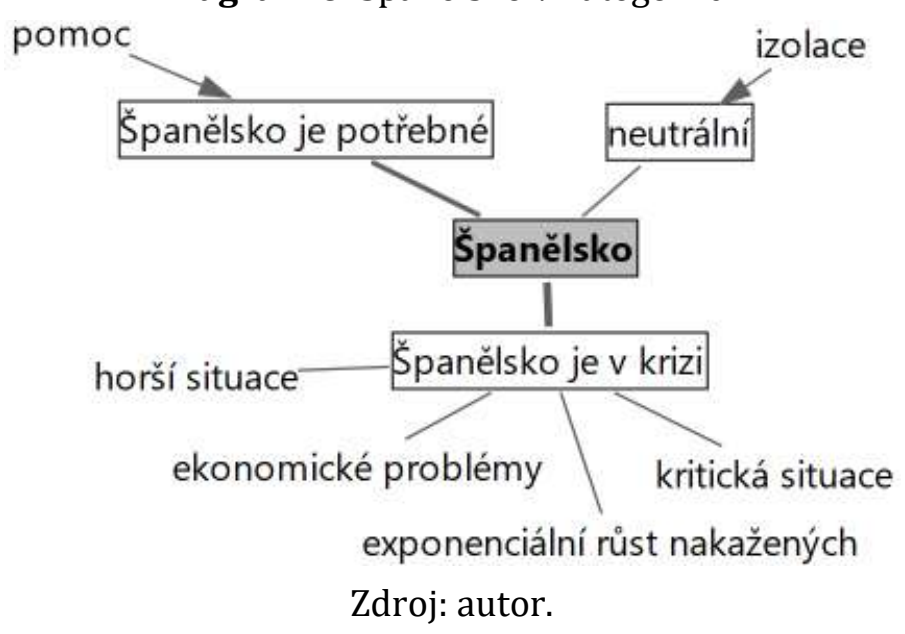

V případě Rakouska jsou pozitivní promluvy pouze tři, zatímco segmenty neutrálních a negativních vyjádření jsou téměř stejně veliké. Pokoušet se interpretovat tato data by bylo značně zavádějící.

V případě Francie v malém vzorku dat převažují negativní vyjádření pod kódy KRITICKÁ SITUACE a NESCHOPNÁ FRANCIE. K interpretaci to opět nestačí. 


\section{Závěr}

Tato práce vznikla z popudu jistého dojmu nevyváženosti a rétorického příklonu k Číně v projevech zkoumaných politiků. V kontextu nejistého vztahu mezi ČR a Čínou si autor textu povšiml náznaků narativizace tohoto vztahu obzvláště v období úvodní fáze krize spojené s pandemií COVID-19 v ČR. Položil si proto výzkumné otázky, jejichž odpověd' má přinést porozumění toho, jak daní politici využili tuto krizi ksdělování svého zahraničněpolitického ideového př́klonu. Jedná se tedy samozřejmě o výzkum velice omezeného výseku reality zahraniční politiky, o výzkum části diskurzivní dimenze. $\mathrm{Na}$ velice omezeném vzorku dat, s jakým pracuje tato studie, není možné zkoumat zahraničněpolitickou orientaci (vektor) en bloc. Chybí především data o nediskurzivní dimenzi zahraniční politiky. Takový cíl si proto práce neklade. Nicméně cíle definovaného v úvodu chce dosáhnou zodpovězením výzkumných otázek: (1) Jaké státy zkoumaní aktéři „narativizovali“ a jakým způsobem a v jaké míře tak činili? (2) Využívali zkoumaní aktéři krizi způsobenou pandemií COVID-19 k artikulaci narativu, který v diskurzivní rovině značí ideovou afilaci ke konkrétní zahraniční entitě (státu)? Pokud ano, k jaké?

Narativní analýza metafor jednoznačně ukázala převahu promluv tematizujících Čínu. Nejdříve byla objevena vysoká kvantita výroků a jejich hodnotově pozitivní náboj, dále byly představeny metafory vyjadřující význam těchto promluv, a nakonec byl rekonstruován narativ. Tento narativ vyobrazuje Čínu jako úspěšnou a pomáhající zemi, kterou ČR potřebuje a se kterou má a měla by mít dobré vztahy. Příběh je určen publiku v ČR a jedná se o př́iběh velice jasný, klidný a bez zvláštních zvratů: je v něm jeden „hrdina“ s jasnými vlastnostmi a záměry. Na základě této analýzy lze konstatovat, že optikou konstruktivistické teorie mezinárodních vztahů ve sledovaném období došlo k tomu, že představitelé vlády ČR a prezident ČR konstruovali narativ o pozitivním charakteru Číny, její pozitivní roli v mezinárodní krizové situaci a pozitivním vztahu mezi ČR a ČLR; touto aktivitou směrem kveřejnosti aktivně komunikovali svoji zahraničněpolitickou afilaci (v hodnotové rovině) k Číně.

Zároveň analýza nebyla schopna rekonstruovat narativ u dalších zemí. Aktéři o nich hovořili zásadně méně, a tak se u nich nedá hovořit o kompletním narativu. Lze tak dojít k závěru, že jejich význam byl ve zkoumaných promluvách upozaděn. U řady z nich byl ovšem dekódován metaforický význam. Lze tak navíc konstatovat několik následujících zjištění. O Evropské unii aktéři hovořili nejasně a ambivalentně, většinou neutrálně, mnohdy čistě pejorativně a v menšině případů jako o partnerovi. Itálie byla líčena vesměs makabrózním scénářem. $V$ případě Německa byla zdůrazňována kritická situace, v menšině případů však představovalo partnerskou zemi. Podobně Španělsko bylo představeno hlavně špatnou situací, i když se objevovala slova podpory vůči této zemi. Jako zcela nejasné se ukázaly promluvy o Rakousku a negativně byla zarámována Francie. Ostatní země nebyly tematizovány vpodstatě vůbec. Pokud ovšem nelze rekonstruovat narativ, nelze ani tvrdit, že se aktéři pokoušeli nějaký vytvářet. Lze říci 
pouze to, že všechny země kromě Číny zůstaly víceméně upozaděny a nárazově byly vyobrazeny spíše pomocí normativně negativních metafor.

Vzhledem k výše uvedenému je možné odpovědět na položené výzkumné otázky. Odpověd' na první výzkumnou otázku zní, že aktéři narativizovali především Čínu. Činili tak takovým způsobem, že pomocí vyprávěného příběhu zasazeného do „kulis“ světové pandemie vyzdvihli pozitivní metafory o roli Číny a o jejím pozitivním charakteru, zatímco upozadili jakoukoliv kritiku. Činili tak v míře 166 metaforicky rámovaných výroků, která odpovídá součtu všech výroků o ostatních zemí (výskyt pozitivních výroků je vyšší čtyřikrát). Ostatní země světa narativizovány nebyly, byly pouze v menší míře a v různém významu metaforicky rámovány. Odpovědí na druhou výzkumnou otázku je, že aktéři krizi využívali mj. k artikulaci narativu, který v diskurzivní rovině značí ideovou afilaci k Číně.

Odpovědí na výzkumné otázky byl naplněn cíl práce, protože poskytuje hlubší porozumění tomu, jak Vláda ČR, poslanci a senátoři vládních stran a prezident ČR jako klíčový aktéři zahraniční politiky ČR v kritické krizové situaci způsobené pandemií COVID-19 využívali zahraničněpolitické narativy, kterými komunikovali určité zahraničněpolitické ideje. Nelze hodnotit, zda je to dáno strategickým záměrem, omylem způsobeným globální chaotickou situací nebo je tento jev prostě důsledkem nezamýšleného účinku. Je ovšem zřejmé, že daný narativ byl v jistém smyslu součástí zahraniční politiky ČR, když se skrze ideové prostředky zahraniční politiky a ústy daných politiků podílel na konstruování určitého diskurzu. V ideové či spíše rétorické rovině tento narativ vykreslil jeden střep zahraničněpolitické mozaiky, diskurzivní tendenci daných politiků kčesko-čínskému partnerství (do jaké míry je tento aspekt funkční v celkové zahraniční politice vůči Číně je otázka na jinou studii).

Celkově lze tedy na základě tohoto zjištění přemýšlet o tom, zda dochází ke snaze měnit zahraničněpolitické směřování ČR a zda je evidentní diskurzivní příklon současného tandemu vláda-prezident k pro-čínské politice součástí širšího a dlouhodobějšího pohybu, který by mohl být završen změnou geopolitického kódu země. To je již samozřejmě naprosto fabulativní úvaha, která v této studii nemá vědeckou oporu. Nicméně dotváří nutný kontext a navrhuje směr uvažování pro další výzkum. Studie totiž ukázala, že zkoumaní politici jsou minimálně velmi angažovaní v pro-čínské rétorice a krizi spojenou s pandemií COVID-19 využili k obhajobě této vlastí politiky.

Přínos studie je za prvé v tom, že se podařilo vědeckou metodou popsat jeden ze způsobů, jak část současné politické elity ČR komunikuje svoji zahraniční politiku, kterou je z hlediska vnějšího pozorovatele většinou obtížné pochopit. Studie implicitně upozorňuje, že pokud chceme porozumět zahraničněpolitickému směřování ČR a dokonce se pokoušet odhadnout jeho budoucí vývoj (za modelových podmínek ceteris paribus), nestačí pouze vnímat oficiální a formální zahraniční policy, ale je třeba mezi řádky neformálních promluv hledat skryté významy. 
Tato studie odhalila významy vpromluvách politiků a zasadila je do konstruktivistické teorie mezinárodních vztahů, když tvrdí, že aktéři konstruovali narativ o Číně, aby tím (záměrně či nezáměrně) komunikovali část své zahraniční politiky. Takový závěr byl interpretován pomocí rigorózního vědeckého postupu, v rámci kterého byla využita metodologická inovace v podobě kombinace narativní analýzy a analýzy metafor. To lze považovat za druhý př́nos studie, protože metoda je využitelná pro další studium diskurzů.

\section{Literatura a seznam zdrojů}

Babiš, A. 2020. „Stenografický zápis 41. schůze, 3. března 2020.“ Parlament České republiky, 3. 3. 2020. [online]. [cit. 14.4020 . 4 20 https://www.psp.cz/eknih/2017ps/stenprot/041schuz/index.htm

Bachrach, P. a Baratz, M. S. 1962. „Two Faces of Power“. The American Political Science Review 56 (4): 947-952. https://doi. org/10.2307/1952796

Bartovic, V. 2016. „Czech Republic: Sending mixed signals“. European Council on Foreign Relations 2016: 4548.

BIS. 2019. „Výroční zpráva Bezpečnostní informační služby za rok 2018“. Bezpečnostní informační služba. [online]. [cit. 12. 4. 2020]. Dostupné z: https://ct24.ceskatelevize.cz/sites/default/files/2394473-2018vz-cz.pdf.pdf

Blecha, I. 2007. Proměny fenomenologie: Úvod do Husserlovy fiosofie. Praha: Triton.

Braun, M. 2009. „Konstruktivismus.“ In: P. Barša a kol. Dialog teorií. Filosofická dilemata výzkumu mezinárodních vztahů. Praha: SLON, 123-144.

Browning, C. S. 2008. Constructivism, Narrative and Foreign Policy Analysis. A Case Study of Finland. Bern: Peter Lang.

Buzan, B. 1991. People, States and Fear: An Agenda for International Security Studies in the Post-Cold War Era. London: ECPR Press.

Buzan, B. a Hansen, L. 2009. The Evolution of International Security Studies. Cambridge: Cambridge University Press.

Campbell, D. 1998. National Deconstruction: Violence, Identity, and Justice in Bosnia. Minnesota: University of Minnesota Press.

Campbell, D. 1999. Writing Security. United States Foreing Policy and the Politics of Identity. Minnesota: University of Minnesota Press.

ČTK 2020. „Respekt: Čína kritizovala přijímání pomoci od Tchaj-wanu. Dodal roušky i ventilátory.“ Česká tisková kancelár. [online]. [cit. 20. 4. 2020]. Dostupné z: https://zpravy.aktualne.cz/domaci/respektcina-kritizovala-prijimani-pomoci-od-tchaj-wanu-doda/r 6c1c20d4827311ea8972ac1f6b220ee8/

Debnam, G. 1975. „Nondecisions and Power: The Two Faces of Bachrach and Baratz.“ American Political Science Review 69 (3): 889-899. https://doi.org/10.2307/1958397

Drulák, P. 2009. Metafory studené války. Interpretace politického fenoménu. Praha: Portál. 
Eriksen, T. H. 2008. Sociální a kulturní antropologie. Př́buzenství, národnostní př́slušnost, rituál. Praha: Portál.

Evans, G. a Newnham, J. 1998. Penguin Dictionary of International Relations. London: Penguin Books.

Fedina, M. 2011. „Metafory v politickém diskurzu Václava Klause.“ E-Polis [online]. [cit. 5. 5. 2020]. Dostupné z: http://www.e-polis.cz/clanek/metafory-v-politickem-diskurzu-vaclava-klause.html

Feisal, M. a Hassan, M. 2012. „Investigating the mind of a terrorist: Grasping the nexus between ideology and narrative." Counter Terrorist Trends and Analyses 4 (5): 7-10.

Feyyaz, M. 2015. „Why Pakistan Does Not Have a Counterterrorism Narrative.“ Journal of Strategic Security 8 (1): 63-78. https://dx.doi.org/10.5038/1944-0472.8.1.1409

Freeden, M. 1996. A Ideologies and Political Theory Conceptual Approach. Oxford: Oxford University Press.

Fridmanová, M. 2005. „Paul Ricoeur: Problém interpretácie a porozumenia.“ FILOZOFIA 60 (3): 192-197.

Fürst, R. a Pleschová, G. 2010. „Czech and Slovak Relations with China: Contenders for China's Favour.“ Europe-Asia Studies 62 (8): 1363-1381. https://dx.doi.org/10.1080/09668136.2010.504387

Gadamer, H.-G. 2009. Pravda a metoda I: Nárys filosofické hermeneutiky. Praha: Triáda.

Garcia, S. 2017. By Tweet and By Speech: An Examination of Values in Donald Trump's Metaphor. Dizertační práce. San Marcos: Texas State University.

Guzzini, S. 2000. „A Reconstruction of Constructivism in International Relations.“ European Journal of International Relations 6: 147-182. https://doi.org/10.1177/1354066100006002001

Hájek, M. 2014. Čtenář a stroj. Vybrané metody sociálněvědní analýzy textů. Praha: SLON.

Hamáček, J. 2020a. Twitter. [online]. [cit. 10. 4. 2020]. Dostupné z: https://twitter.com/jhamacek/status/1240952715066462208

Hamáček, J. 2020b. Facebook. [online]. [cit. 10. 4. 2020]. Dostupné z: https://www.facebook.com/129237636702/posts/10158143646511703

Hamáček, J. 2020c. Twitter. [online]. [cit. 10. 4. 2020]. Dostupné z: https://twitter.com/jha macek/status/1244246093489111040

$\begin{array}{llllllll}\text { Hamáček, J. 2020d. Twitter. } & \text { [online]. } & \text { [cit. } & 8 . & 4 . & 2020\end{array}$. https://twitter.com/jhamacek/status/1242491715812044800

Hamáček, J. 2020f. „Stenografický zápis 41. schůze, 3. března 2020.“ Parlament České republiky, 3. 3. 2020.

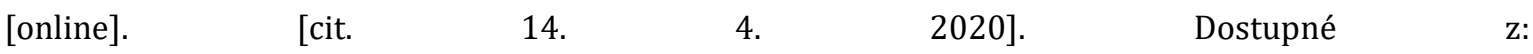
https://www.psp.cz/eknih/2017ps/stenprot/041schuz/index.htm

Havlíček, K. 2020a. Twitter. [online]. [cit. 8. 4. 2020]. Dostupné z: https://twitter.com/KarelHavlicek_/status/1240510859941740544

Charteris-Black, J. 2004. Corpus Approaches to Critical Metaphor Analysis. London: Palgrave MacMillan.

Chatman, S. 2008. Př́běh a diskurs. Narativní struktura v literatuře a filmu. Brno: HOST.

Cheema, Q. a Shamil, T. 2017. „21st Century and Pakistan's New Narrative for National Stability.“ Strategic Studies 37(4): 133-148.

Koutník, O. 2020. „Snažíme se domů dostat 20 tisíc lidí. Někteří mi vyrážejí dech, říká ministr." Seznam zprávy. [online]. [cit. 7. 5. 2020]. Dostupné z https://www.seznamzpravy.cz/clanek/snazime-se-domudostat-20-tisic-lidi-nekteri-mi-vyrazeji-dech-rika-ministr-95716 
Kratochvíl, P. 2015. „The Czech Republic: Lacking Foreign Policy Consensus.“ Europe Policy Paper 2015 (1): $12-15$.

Krebs, R. 2015. Narrative and the Making of US National Security. Cambridge: Cambridge University Press.

Labov, W. 2006. „Narrative Pre-construction." Narrative Inquiry 16 (1): 37-45. https://doi.org/10.1075/ni.16.1.07lab

Langová, M. 2020. „Doufám, že omezení skončí co nejdřiv.“ Lidové noviny. [online]. [cit. 6. 5. 2020]. Dostupné z: https://www.lidovenoviny.cz/nahled.aspx?d=31.03.2020\&e=LN-PRAHA\&id=9228888

Lewis, W. 2009. „Telling America's story: Narrative form and the Reagan presidency.“ Quarterly Journal of Speech 73 (3): 280-302. https://doi.org/10.1080/00335638709383809

Marder, L. 2018. „Refugees Are Not Weapons: The “Weapons of Mass Migration” Metaphor and Its Implications." International Studies Review 20 (4): 576-588. https://doi.org/10.1093/isr/vix055

Miskimmon, A., O'Loughlin, B. a Roselle, L. 2017. Forging the World: Strategic Narratives and International Relations. Michigan: University of Michigan Press.

Nguyen, T. 2020. „Tak velké haló z Číny děláme jen u nás, rríká ministr zahraničí Petříček." E15. [online]. [cit. 7. 5. 2020]. Dostupné z: https://www.e15.cz/clanek/1368224/tak-velke-halo-z-ciny-delame-jen-u-nasrika-ministr-zahranici-petricek

Oppermann, K. a Spencer, A. 2016. „Telling stories of failure: narrative constructions of foreign policy fiascos." Journal of European Public Policy 23 (5): 685-701. https://doi.org/10.1080/13501763.2015.1127272

Ovčáček, J. 2020. Twitter. [online]. [cit. 15. 6. 2020]. Dostupné z: https://twitter.com/PREZIDENTmluvci Pavelka, J. 1982. Anatomie metafory. Brno: Blok.

Pehe, J. 1999. „Connections between Domestic and Foreign Policy.“ Mezinárodní vztahy 34 (2): 61-64.

Petř́ček, T. 2020a. Facebook. [online]. [cit. 15. 4. 2020]. Dostupné z: https://www.facebook.com/161427891133651/posts/566801513929618

Petříček, T. 2020b. „Petříček: Dva roky zavřených hranic byl černý scénář. Závislost na Číně je ponaučení“” DVTV. [online]. [cit. 18. 4. 2020]. Dostupné z https://video.aktualne.cz/dvtv/petricek-dva-rokyzavrenych-hranic-je-cerny-scenar-zavislost/r 2741b7067e8311ea842f0cc47ab5f122/

Pope, P. 2017. "Constructing the Refugee as Villain." World Affairs 180 (3): 53-71. https://doi.org/10.1177/0043820018757542

Právo. 2020. „Zeman udělí Prymulovi Řád bílého lva.“ Právo. [online]. [cit. 5. 5. 2020]. Dostupné z: http://pravo.novinky.cz/

Ricoeur, P. 2000. Čas a vyprávění I. Praha: OIKUMENH.

Ricoeur, P. 2007. Čas a vyprávění III. Praha: OIKUMENH.

Rittberger, V. 2004. Approaches to the Study of Foreign Policy Derived from International Relations Theories.

Tübingen: University of Tübingen, Center for International Relations/Peace and Conflict Studies, Institute for Political Science.

Shabu, M. 2020. „Ministři se chytli na síti. Hamáček se následně kál a Vojtěch nechtěně přiznal, že komunikace skř́pe." Lidové noviny. [online]. [cit. 12. 4. 2020]. Dostupné $\mathrm{z}$ https://www.lidovky.cz/domov/nervy-zapusobily-vladni-ministri-si-na-twitteru-vymenili-ostrenazory-byla-to-chyba-rika-hamacek.A200329_200438_ln_domov_ele 
Slačálek, 0. 2009. „Postmodernismus.“ In: P. Barša a kol. Dialog teorií. Filosofická dilemata výzkumu mezinárodních vztahů. Praha: SLON, 145-176.

Stulík, O. 2013. „Analýza dělnických listů.“ Rexter 2013 (1): 35-70.

Stulík, 0. 2016. Liberální demokracie (ne)rozumu: Popper a ti druzí v analýze metafor. Praha: CDK.

Stulík, O. a Krčál, P. 2019. „Surfování na migrační vlně v době populismu: Sekuritizace migrace ze strany poslanců Parlamentu České republiky.“ Acta Politologica 11 (2): 1-17. https://doi.org/10.14712/18038220/8_2019

Subotić, J. 2016. „Narrative, Ontological Security, and Foreign Policy Change.“ Foreign Policy Analysis 12 (4): 610-627. https://doi.org/10.1111/fpa.12089

Teitler, A. 2017. „Obama and Afghanistan: a constructivist approach to shifting policy narrative and practices." Cambridge Review of International Affairs $31 \quad$ (2): 203-222. https://doi.org/10.1080/09557571.2018.1497009

Tsvetov, A. 2016. „After Crimea: Southeast Asia in Russia's Foreign Policy Narrative.“ Contemporary Southeast Asia 38 (1): 55-80, http://dx.doi.org/10.1353/csa.2016.0003

Vláda České republiky. 2020a. „Tisková konference po mimořádném jednání vlády, 17. března 2020.“ Vláda České republiky. [online]. [cit. 8. 4. 2020]. Dostupné z: https://www.vlada.cz/cz/mediacentrum/tiskove-konference/tiskova-konference-po-mimoradnem-jednani-vlady--17--brezna-2020180412/

Vláda České republiky. 2020b. „Tisková konference po jednání vlády, 16. března 2020.“ Vláda České republiky. [online]. [cit. 8. 4. 2020]. Dostupné z: https://www.vlada.cz/cz/media-centrum/tiskovekonference/tiskova-konference-po-jednani-vlady--16--brezna-2020-180384/

Vláda České republiky. 2020c. „Tisková konference k rozhodnutí vlády o uzavření všech obchodů kromě prodejen potravin, lékáren, drogerií, čerpacích stanic a dalších, 14. března 2020. "Vláda České republiky. [online]. [cit. 14. 4. 2020]. Dostupné z: https://www.vlada.cz/cz/media-centrum/aktualne/vladarozhodla-o-uzavreni-vsech-obchodu-krome-prodejen-potravin--lekaren--drogerii--cerpacich-stanic-anekterych-dalsich-180327/

Vláda České republiky. 2020d. „Tisková konference po mimořádném jednání vlády, 17. března 2020.“ Vláda České republiky. [online]. [cit. 14. 4. 2020]. Dostupné z: https://www.vlada.cz/cz/mediacentrum/aktualne/vlada-rozhodla-o-uzavreni-vsech-obchodu-krome-prodejen-potravin--lekaren-drogerii--cerpacich-stanic-a-nekterych-dalsich-180327/

Vojtěch, A. 2020. „Stenografický zápis 41. schůze, 3. března 2020.“Parlament České republiky, 3. 3. 2020.

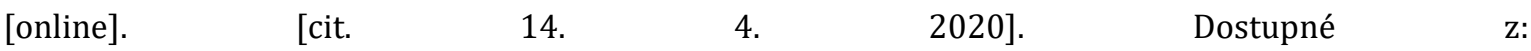
https://www.psp.cz/eknih/2017ps/stenprot/041schuz/index.htm

Weiss, T. a Řiháčková, V. 2010. „Promoting Multilateralism? Conceptualizing Multilateralism in the Czech Foreign Policy." Perspectives 18 (1): 5-21.

Wendt, A. 1999. Social Theory of International Politics. Cambridge: Cambridge University Press.

Zázvorka, J. 2020. „Nejsem spokojen, investujte v Česku víc, řekl Zeman v čínské televizi.“ iDNES. [online]. [cit. 23. 4. 2020]. Dostupné z: https://www.idnes.cz/zpravy/domaci/zeman-cina-investice-rozhovorkritika.A190423_173856_domaci_zaz 
Central European Journal of Politics Volume 6 (2020), Issue 2, pp. 44-72

Zeman, M. 2020a. Facebook. [online]. [cit. 8. 4. 2020]. Dostupné z: https://www.facebook.com/417747541641010/posts/2852011994881207

Zeman, M. 2020b. „Projev prezidenta republiky k národu čtvrtek 19.03.2020.“ Pražský hrad, 19. 3. 2020. [online]. [cit. 13. 4. 2020]. Dostupné z https://www.hrad.cz/cs/video/projev-prezidenta-republiky-knarodu-15338 